Article

\title{
Is Edu-Tourism a Sustainable Option? A Case Study of Residents' Perceptions
}

\author{
Habib Alipour ${ }^{1, *}$, Hamed Fatemi ${ }^{1}$ and Nahid Malazizi ${ }^{2}$ (D) \\ 1 Faculty of Tourism, Eastern Mediterranean University, Famagusta/TRNC. Via Mersin 10, \\ Famagusta 99450, Turkey; fatemi_hamed@yahoo.com \\ 2 Faculty of Tourism, Onbes Kasim Kibris Universitesi, Lefkosa/TRNC. Via Mersin 10, Nicosia 99010, Turkey; \\ nahidmalazizi@onbeskku.edu.tr \\ * Correspondence: habib.alipour@emu.edu.tr
}

Received: 28 April 2020; Accepted: 28 June 2020; Published: 23 July 2020

\begin{abstract}
In studies of the impact of tourism, considerable attention has been given to the attitudes and perceptions of host communities toward tourism. However, most of these studies have focused on tourism in general and on sporadic alternative tourism in particular. This study aims to fill a gap in the research literature by examining residents' perceptions of the economic, socio-cultural, and environmental sustainability of edu-tourism. It contributes to the limited literature on edu-tourism and to that on residents' perceptions of tourism in small island developing states. A sample of $300(\mathrm{~N}=300)$ residents was surveyed in the city of Famagusta in Northern Cyprus to investigate residents' attitudes toward the sustainability of edu-tourism. ANOVA and Cramér's V tests were applied to analyze the perceptions of residents of the social, economic, and environmental impacts of edu-tourism. The influence of the socio-demographic characteristics of the residents on their perceptions and attitudes was of these issues was also examined. The study revealed that there is a variety of attitudes among residents toward the sustainability of edu-tourism and that, although residents are generally positive about edu-tourism, attitudes toward its social and environmental sustainability are mixed.
\end{abstract}

Keywords: residents' perception; edu-tourism; community impacts; sustainability; edu-tourism destination

\section{Introduction}

There is a general consensus that tourism is recognized as a significant sector of the economy because of the diverse roles it plays in the life of a community and its ability to have a positive impact on residents' quality of life [1-4]. The outcomes and impacts of mass tourism have been studied from the residents' perspective with respect to its social, cultural, economic, and environmental impacts, both negative and positive [5-9].

The negative impacts of tourism, in general, on residents' environmental, economic, and cultural wellbeing, as well as their overall livelihood, have spurred a great deal of research on residents' perceptions of tourism [10-12]. 'Residents have gained importance in the tourism equation, as their perceptions indicate tourism's outlook regarding sustainability' ([13], p. 277). While the positive impacts of tourism are welcomed, the negative impacts are what have mainly attracted researchers to focus on this topic, so as to provide pathways to policymakers to reduce and minimize the negative outcomes of tourism $[4,5,14,15]$.

However, tourism is a multidimensional and multifaceted industry that encompasses a variety of sectors, sub-sectors, stakeholders, and agencies [16]. There are, moreover, numerous types of 
tourism, each with its own unique structure and definition depending on the types of tourists, services, resources, patterns of travel, markets, and expectations [17,18].

The main focus of this study is educational tourism or international educational tourism (hereafter, edu-tourism), as it has become a major tourism niche, especially in island states [19,20]. As edu-tourism is embedded in the very communities that residents share with edu-tourists on a long-term basis, residents' perception of the sustainability of this form of tourism (i.e., based on a triple-bottom-line approach, taking into account the economic, socio-cultural, and environmental impacts) is imperative for their support and acceptance.

Edu-tourism is a type of tourism (i.e., a separate niche) (McGladdery and Lubbe, 2017) that encompasses a particular tourism activity, which education, learning, and knowledge gaining is the main purpose of travel (Ritchie, 2003). The patrons of this so-called niche tourism are international students (i.e., edu-tourists) who travel away from home country to overseas (i.e., destination) for the purpose of education (Stoner et al., 2014). According to $\operatorname{OECD}(2018$, p. 38-39), what constitutes edu-tourism 'are individuals [edu-tourists] who have physically crossed an international border between two countries with the objective of participating in educational activities in the country of destination, where the country of destination is different from their country of origin'. Furthermore, edu-tourists are enrolled as regular students in any semester/term of a program taught in the country of destination with the aim of graduating from it in the country of destination and are expected to attend all the courses taught.

Edu-tourism also emanates from globalization, which 'brings greater mobility, not only of people but also of all manner of life forms, resulting in a transforming, bio-socially world' ([21], p. 2). Only a limited number of studies of edu-tourism have been carried out, and the literature on residents' perception of this form of tourism is almost non-existent. This is perhaps because of the expanse of tourism-related subjects and the dispersed nature of edu-tourism spatially. However, it is evident that 'the academic study of educational tourism had not kept pace with industry growth' ([22], p. 2) and that 'there is limited understanding of educational tourism constructs as well as an absence of research into the diverse intellectual tourism market segments' (as cited in [23], p. 58).

Edu-tourism is also considered an alternative form of tourism due to its product, process, and function; it has a low market volume, is locally controlled, and functions within the environmental, social, and economic carrying capacities of the destination [24]. Edu-tourism has also been classified as an alternative type of tourism characterized by its manageable size and purpose-specific nature. However, it has remained an understudied branch of alternative tourism [22].

This study specifically analyzes the value of residents' perceptions of edu-tourism and its sustainability, knowing that understanding their perceptions is a necessary part of assessing the sustainability of any tourism development [25-27]. However, edu-tourism, notwithstanding its categorization as an alternative form of tourism, has unique characteristics and a distinct nature in terms of its nesting within the community and with respect to the interaction of the tourists with the residents. The uniqueness of edu-tourism is manifest in its structure, as edu-tourists are embedded in the university town in a manner that has spatial (i.e., sharing the same space with the residents throughout the duration of their study) as well as temporal implication (i.e., the long-term nature of the interaction between the residents and edu-tourists).

Sustainable tourism entered the lexicon of global tourism in response to the negative social, economic, and environmental impacts of mass tourism, which elaborated by several publications including De Kadt (1979), Bryden (1973), Britton (1983, 1996), and Burns (1999). This early critique of mass tourism coupled with United Nations' Agenda 21 (1992) pawed the way for promotion of so-called 'alternative' tourism that supposed to be sustainable and limit the negative impacts of mass tourism. However, the clear definition of alternative tourism remains contentious (Higgins-Desbiolles, 2008). Nevertheless, labels for the alternative to mass tourism varies in the literature, but the assumption is that they possess the characteristics of sustainable tourism. The labels include 'alternative tourism' (Pearce, 1992), 'responsible tourism' (Musavengane, 2019), 'new tourism' (Poon, 1994), 'soft tourism' 
(Slee et al., 1995), 'low-impact tourism' (Gössling, 2000), 'special interest tourism' (Trauer, 2006), Pro-poor tourism (Ashley \& Roe, 2001), sustainable tourism' (Butler, 1999), and edu-tourism (OECD, 2019; McGladdery \& Lubbe, 2017). One of the major characteristics of all forms of alternative tourism that qualify them as 'sustainable' is that the high percentage of tourist expenditure remains with the local population in contrast to global mass tourism, which is associated with leakage and pre-leakage (i.e., a large portion of tourist expenditure transferred to the core rather than contributing to the destination) (Holden, 2016).

The relevance and novelty of this research is twofold; first, edu-tourism has become a formidable form of alternative/niche tourism not only in developed economies, but also in developing and small island states, and specifically in north Cyprus (Katercioğlu, 2010). Nowadays, edu-tourism illustrates a mobility 'in which people travel across international borders to acquire intellectual services' (Abubakar et al., 2014, p. 59). The demand structure of edu-tourism is reinforced by the fact that in todays' globalized world, 'people travel across international borders to acquire intellectual services and countries are channeling more fund in education for the purpose of tourism' (Abubakar et al., 2014. p. 59). Educational institutions have also adopted English language as the medium of teaching that gives them a competitive edge. The flow of edu-tourists from developing countries has also affected by level of economic growth and global political/social involvement of the home country, and availability of educational opportunities in the supply side (destination) (McMahon, 1992). Presence of a measurable number of African students in north Cyprus universities is a testament to the demand and supply structure (Katircioğlu, 2010). The assumption is that the residents' perception of edu-tourism differs from other forms of tourism because of two essential attributes of edu-tourists (guests). First, a spatial attribute meaning that sharing the same space in a highly interactive way with the residents; secondly, a temporal attribute (i.e., that is the length of the staying in the host community). There is no any other form of tourism with such attributes. Edu-tourism has become the economic backbone of the studied communities and the spatial as well as temporal attributes render a condition (i.e., in average each edu-tourist spends five years in the destination) that profoundly affects the social, cultural, and environmental structure of the host community (Paul, 2010).

Edu-tourism is the main economic base in the case of north Cyprus and the main contributor to employment and income. Therefore, its sustainability is vital for the future wellbeing of these communities. Small islands are also limited in resources and highly dependent on mass tourism (UN, 2019). However, as Hampton and Jeyacheya (2020, p. 9) noted: 'the business model currently adopted by many small island developing states (SIDS) is mass tourism, of which transnational corporations (TNCs) are the primary beneficiaries. Success is presently largely measured in terms of the value and volume of international visitor arrivals, yet local communities and the environment often suffer'. Edu-tourism is an alternative to mass tourism as it benefits the communities. However, for edu-tourism to become a sustainable option, understanding the residents' attitude is fundamental for sustainable tourism planning and management (Alrwajfah et al., 2019).

Thus, our pioneering study sheds light on the sustainability of edu-tourism, especially in island states with limited resources that have tourism-dependent economies [28]. Therefore, this study focuses on the residents' perception because they are at the forefront of this form of tourism and they need to bear the brunt of its impact [29]. We hypothesize that the influence of edu-tourism on the residents' perception of its sustainability differs from other forms of tourism because of the spatial and temporal characteristics of edu-tourism.

The organization of the rest of the article is as follows: The Section 2 offers insights into edu-tourism and introduces the concept of sustainability in tourism from the literature. The Section 3 focuses on the residents' perceptions and relevant theoretical frameworks for understanding them; the Section 4 details the methodology; the Section 5 presents a discussion and concluding remarks; and the Section 6 focuses on implications, limitations, and suggestions for future research. 


\section{Conceptualization}

Almost all of the globalization of international education/educational tourism theorists who inform our study are influenced by the theory of experiential learning, which 'explains the manner in which learning occurs during the international education tourism [as well as] global learning theory that describes the generic, as opposed to subject-specific, desired outcomes of international educational tourism' ([22], p. 6-7). Based on these theories, Knight [30] defines international education as 'the process of integrating an international, intercultural, or global dimension into the purpose, function or delivery of post-secondary education' (p. 11).

Furthermore, the internationalization of education (edu-tourism) has been analyzed in the context of mobility theory and spatial theory. Larson [31] notes that 'gone are the days when we could associate particular programs with a university grounded in a particular place, and students who only attended the university in the place they considered home' (p. 123).

Edu-tourism, which is a manifestation of the internationalization of education, has been conceptualized in the context of "mobilities" in the epistemology of tourism [32]. In the context of edu-tourism, mobilities are described as "encompassing both the large-scale movements of people, objects, capital and information across the world, as well as the more local processes of daily transportation, movement through public space and the travel of material things within everyday life" (as cited in [33], p. 82). It is in this context that we argue that residents are taking center stage, as they are in constant contact in time (temporally) and space (spatially) with the edu-tourists.

Notwithstanding the ubiquity of the SET in the literature on residents' perceptions of the impact of tourism analysis (Gursoy et al., 2019), it is still 'centered on every interaction as exchange and founded on the scheme on the giving and returning equivalence' (Zafirovski, 2005, p. 16). Thus, the social interaction/exchange is reduced to economic transaction. However, our study adds to our knowledge and understanding of residents' perception that transcends the economic transaction, which is the central proposition of SET. Moreover, by bringing the 'sustainability' concept into the process of analysis, it is realized that the SET overlooks the societal and environmental framework of exchanges. It also offers a mechanistic approach to human action.

$\mathrm{Xi}$ et al. [34] described the scope of mobilities in terms of their spatial, infrastructural, and institutional moorings in tourism. Thus, the main question is: How do residents who share space and time with edu-tourists perceive this form of tourism? The sustainability of this form of tourism from the residents' point of view has never been investigated; this study will be the first attempt to answer this question. For the conceptual model of the study, see Figure 1.

With the rise of the knowledge economy and prominence of information technology, coupled with mobility and globalization, some island states have restructured their economies towards developing transnational education (Mok, 2008). Nowadays, governments in Hong Kong, Singapore, Taiwan, Mauritius, and the Caribbean islands have strategized their competitiveness and are very keen to develop the island states as a regional hub of higher education (Mehtap-Smadi and Hashemipour, 2011; Mok, 2008; Sutton, 2008). Ward (2001) asserts that international students (edu-tourists) will likely affect the host community and their institutions; therefore, this study is responding to Ward's call for further research in this topic.

By far and due to the explanatory power of the social exchange theory (SET), it has been utilized by researchers extensively to understand the residents' perceptions of tourism (Hadinejad et al., 2019; Gursoy et al., 2018; Nunkoo et al., 2013; Rasoolimanesh et al., 2016). However, SET initially focused on the benefit and cost of tourism that residents' perceptions predicated on (i.e., mainly an economic dimension oriented) (Goodwin, 2017; Cropanzano \& Mitchell, 2005; Heath and Heath, 1976). As the issue of sustainability of tourism gained ground, researchers began to add the social and environmental dimensions into the investigation of residents' perceptions (Olya et al., 2018; Choi \& Murray, 2010). 


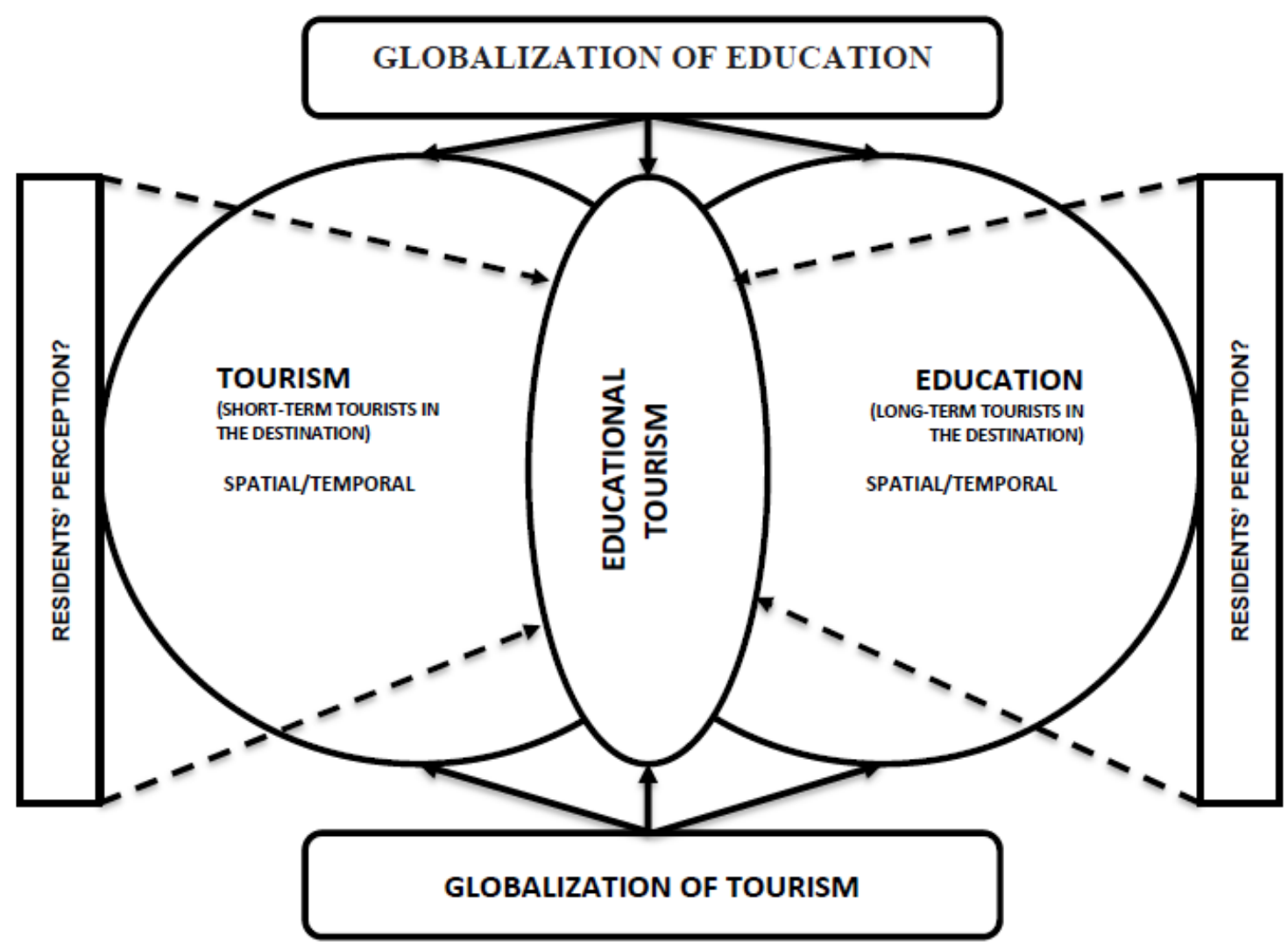

Figure 1. Conceptual model. Source: Adopted from Ritchie [17] (p. 13).

\section{Literature Review}

\subsection{Edu-Tourism: An Overview}

According to Bodger [35], edu-tourism refers to any 'program in which participants travel to a location as a group with the primary purpose of engaging in a learning experience directly related to the location' (p. 28). Several scholars have defined edu-tourism as 'it involves travel away from one's home with either the primary or secondary purpose being to learn in a unique environment" (as cited in [22], p. 320). Matoga [36] noted that 'commercial trips functioning in accordance with the traditional model of tourism of ' $3 S^{\prime}$ ' (sun, sea, and sand) are being replaced by the model of tourism of ' $3 \mathrm{E}^{\prime}$ (entertainment, excitement, and education), where tourists are more focused on fulfilling their cognitive needs rather than relaxing passively in seaside resorts' (p. 564).

Educational tourism has also gained prominence as a tool for regional development around the world [37]. 'Between 2010 and 2017, the share of incoming mobile students increased in nearly all countries with data available' ([38], p. 230] (see Figures A1 and A2 Appendix A).

Nowadays, with the growth of tourism as a global phenomenon and the ubiquity of access around the world, mobility for the purpose of education has become a driving force for various small states and islands. According to the OECD [38]:

'Mobile students refer to both international students (those who cross borders for the sole purpose of study) and foreign students (students who do not hold the same nationality as the host country), whose number is used in some countries as a proxy measure for the number of international (cross-border) students' (p. 230).

Therefore, far-away destinations, from a highly developed country to a small island state, have become hubs of education and research $[20,23]$ According to a report by the Organization for Economic Cooperation and Development (OECD), over the past three decades, the number of university students enrolled outside their home countries has risen from 0.8 million in 1975 to 4.5 million in 2012, 
a more-than-fivefold increase [39]. Interestingly, small cities have also been involved in regeneration through edu-tourism by programs such as the Small Cities Community-University Research Alliance (CURA) [40].

For instance, Northern Cyprus, on a small island in the Eastern Mediterranean, has become a hub of higher education in the last decade. According to YÖDAK [41], the expenditure of foreign students account for $40 \%$ of the economy, and the state is home to 20 universities with 102,000 students.

Edu-tourism has become an export industry around the world and has grown into a multi-billion-dollar sub-sector of global tourism, in which the pursuit of education is the main motivation [40,42]. As Katircioglu [43] (p. 1956-7) notes, 'higher education is an important global phenomenon. Each year millions of people pursue their higher education at overseas institutions. Thus, higher education can be considered as a type of student tourism [edu-tourists] that contributes to national income, employment, and the wealth of local citizens.'

\subsection{Sustainability and Edu-Tourism}

The concept of sustainable tourism has been the subject of research and discussion for the last four decades when it was realized that mass tourism is not a neutral phenomenon; on the contrary, it affects the whole socio-ecological system in both negative and positive ways [44]. The changing perception and realization of the negative impacts of tourism was initiated by De Kadt [45], and by the establishment of The Journal of Sustainable Tourism in 1993, which focused on research to explore pathways toward mitigating the negative impacts of mass tourism. This has also aimed to provide a unique insight into the complex and rapidly evolving world of sustainable tourism [46].

For the purpose of this study, sustainable tourism is defined as 'tourism which is developed and maintained in an area (community, environment) in such a manner and at such a scale that it remains viable over an infinite period and does not degrade or alter the environment (human and physical) in which it exists to such a degree that it prohibits the successful development and well being of other activities and processes' ([46], p. 12).

The urgency of sustainable tourism in small island states is a compelling issue due to their vulnerability, small landmass, lack of resources, and dependency on tourism [8,47]. The vulnerability of small island states to mass tourism and the dependent nature of these socio-ecological systems on tourism poses a formidable challenge in terms of how to manage tourism in a sustainable manner. There is ample evidence of damage due to the negative impacts of mass tourism in various island states $[30,48,49]$.

Thus, edu-tourism has become an alternative to mass tourism and an innovative approach to sustainable tourism development in various island states, including Northern Cyprus [20,45,50,51]. 'The creation of study-abroad schemes, such as ERASMUS (the European Community Action Scheme for the Mobility of University Students), by the European Union' ([17], p. 203) has also paved the way for small islands such as Cyprus to capitalize on edu-tourism as a sustainable option.

Furthermore, with the recognized negative impacts of mass tourism, a move toward "soft" [52] and alternative forms of tourism gained ground in destinations in general and small islands in particular. Nevertheless, edu-tourism, along with rural tourism, ecotourism, adventure tourism, and cultural heritage tourism (to name just a few), has developed into a niche tourism market with a sustainable agenda [17].

However, to explore whether or not edu-tourism is a sustainable option, our study focuses on the main stakeholder: The residents of edu-tourism destinations. This approach is justified as the residents are sharing the same space (spatial) and the time (temporal) with edu-tourists. The affinity that is built between residents and edu-tourists is based on the long-term presence of the host and constant interaction in shared spaces between the hosts and guests. The residents' perception of the triple-bottom-line framework of sustainability (social, economic, and environment) is thus a legitimate source of investigation for the purpose of this research [14,53-61]. Moreover, to the best of 
the author's knowledge, no previous study has investigated the residents' perception of edu-tourism and its sustainability.

Nevertheless, studies on factors influencing residents' perception of tourism impacts, as well as its sustainability, remain highly heterogeneous as evidenced from various studies (Hatertabar, 2020). This also concurs with the fact that communities are not homogeneous entities (Blackstock, 2005). In addition, most of the studies on this topic vary in terms of scope, geographic areas, destinations, population size, theories, and methodologies, not to mention different variables (Sharpley, 2014). Nevertheless, residents are one of the most important and valuable stakeholders for a tourist destination; therefore, their perceptions of tourism and its sustainability is paramount for the destination development strategies and sustaining competitiveness (Hateftabar \& Chapuis, 2020; Ritchie and Crouch, 2003). The role of residents in supporting and accommodating edu-tourists is crucial as this type of tourist is embedded in the community for a long time. Hateftabar and Chapuis (2020, p. 157) stated that 'a lack of community dedication to tourism development or hostile resident behavior toward tourists often leads to the tourists traveling somewhere else'. There is also ample evidence in the literature that hospitality of the residents and their support is a crucial factor for the sustainable development of tourism (Gonzalez et al., 2018; Rasoolimanesh et al., 2015; Zamani-Farahani \& Musa, 2012; Kitnuntaviwat \& Tang, 2008). Based on the social exchange theory (SET), which is used to explain residents' perceptions extensively (Hateftabar \& Chapuis, 2020), people always support and follow whatever that is valuable for them. However, the impact of excessive tourism development alarmed not only the experts, but also the residents, to be concerned about sustainability of tourism (Nunkoo \& Ramkissoon, 2010). In addition, the impact of the excessive development of tourism has also provoked considerable discussions about sustainability of tourism (Hardy et al., 2002; Jackson \& Morpeth, 1999). Therefore, we posit the following hypothesis:

Hypothesis 1 (H1). Gender is considered as an intrinsic variable influencing residents' perception toward sustainability of edu-tourism.

Hypothesis 2 (H2). Marital status is considered as an intrinsic variable influencing residents' perception toward sustainability of edu-tourism.

Hypothesis 3 (H3). Age is considered as an intrinsic variable influencing residents' perception toward sustainability of edu-tourism.

Hypothesis 4 (H4). Income is considered as an extrinsic variable influencing residents' perception toward sustainability of edu-tourism.

Hypothesis 5 (H5). Occupation is considered as an extrinsic variable influencing residents' perception toward sustainability of edu-tourism.

Hypothesis 6 (H6). Education is considered as an extrinsic variable influencing residents' perception toward sustainability of edu-tourism.

Hypothesis 7 (H7). Length of residency is considered as an intrinsic variable influencing residents' perception toward sustainability of edu-tourism.

\subsection{Residents' Perceptions and Attitudes}

Residents' perceptions of and attitudes toward tourism development in general and sustainable tourism in particular have been studied extensively $[4,5,27,62-67]$. Furthermore, as residents are at the forefront of the impact of tourism, analyzing their attitudes toward and perceptions of the sustainability 
of tourism is important, as they are influenced by factors including the social, cultural, economic, and environmental impacts of tourism $[1,68,69]$.

As residents are recognized to be the main stakeholders, analysis of their perceptions has gained prominence in the fields of tourism development and sustainability. The voluminous studies that have employed numerous theories to investigate residents' perceptions of the impacts of tourism, including growth machine theory [70], community attachment theory [27], social representation theory [71], the theory of rationality and empowerment [72], and emotional solidarity theory [73] are a testimony to the importance of residents. However, social exchange theory (SET) remains the most frequently cited and influential theory in the literature on the analysis of residents' perception $[60,74]$.

In the meantime, residents' perceptions have been studied in terms of the economic, social, cultural, and environmental impacts of tourism in the context of sustainable development $[4,5,13,14,31,75-77]$. In addition, some scholars have examined how certain attributes affect the residents' perceptions of the impacts of tourism, including length of residency, demographic characteristics, personal benefits, and the community's overall dependency on tourism (e.g., a university town's dependency on edu-tourism) [4,78-80].

The most dominant theory utilized to investigate residents' perceptions of the impacts of tourism and of the sustainability of tourism is social exchange theory (SET) [81,82]. SET has been one of the major theoretical perspectives in the field of social psychology since the early writings of Thibaut and Kelly [83] and Homans [84]. "Social exchange theory emphasizes the perceived costs and benefits of a certain relationship as well as the implication on the relationship satisfaction of the parties involved" (as cited in [85], p. 174-5). Nevertheless, it is claimed that "exchange" is a social characteristic that hosts and tourists encounter in the context of traveling.

The literature has also emphasized the role of residents in the successful outcome of tourism development, especially if the sustainability of tourism is at stake $[3,86]$. In the tourism governance context, and within the co-management framework, residents' participation in tourism planning and development "is particularly relevant since the negative effects of tourism mostly manifest on the destination level as a burden for local residents" [87].

\subsection{Residents' Perceptions of Sustainable Tourism}

While the sustainability of edu-tourism is the main point of research in this study, conceptualizing and explaining residents' perception of this form of tourism should transcend the two-dimensional framework (i.e., benefits and costs) that has been dominant method in the context of SET [88,89]. Such a framework has also been critiqued for being highly oriented toward the economic aspects. However, notwithstanding the positive economic benefits, residents in different destinations have often been dismayed by over-tourism [90,91], which has significant negative implications, especially with regard to the social and environmental impacts [14,92-94].

Thus, SET may not explain the residents' perceptions of and support for the sustainability of tourism regardless of the economic benefits [78]. Therefore, when it comes to the residents' perception of edu-tourism's sustainability, this study attempts to transcend the simple formula (i.e., behavior (profits) = rewards of interaction - costs of interaction) [95]. To achieve the aim of this study, we focus on residents' perceptions of edu-tourism by applying a triple-bottom-line approach (i.e., a three-dimensional framework) to the evaluation that takes into account economic, social, and environmental impacts. The latter approach, which is used in this study, integrates and interrelates the environmental, social, and economic dimensions as pillars of sustainability. Therefore, we extend the coverage to include non-economic themes, which is motivated by the fact that the socio-ecological systems will not be successfully managed unless a holistic view is adopted [96].

Nevertheless, the residents' perceptions can also be affected by latent constructs, including community attachment [97], level of tourism planning and development [98,99], quality of life satisfaction [1,3], and overall sustainability of tourism [79]. While SET is an economics-fixated paradigm [75], the issue of sustainability remains unanswered. In addition, this aspect is understudied 
in investigations of residents' perception in the context of SET. Our study is an attempt to highlight this void. Host communities' perception of sustainability of edu-tourism is more complicated when the effects of demographic variables are factored in [90]. Xu et al. [4] believe that the socio-demographic characteristics of residents should be a baseline for future follow-up or longitudinal studies. Our study has factored in the characteristics that should be calibrated in studies of community perceptions in the context of sustainability.

Conventional studies examining residents' perceptions of tourism development focused on the range of positive impacts (e.g., benefits, employment, quality of life, and cultural exchange), and negative impacts (e.g., increase in price, traffic congestion, damage to environment) (Andereck \& Nyaupane, 2011; Gursoy \& Rutherford, 2004). With the concern over sustainability of tourism in response to negative impacts of mass tourism as well as the complexity of residents' attitudes, a more holistic/integrated approach introduced to understand residents' perceptions. Therefore, tourism impacts require to be investigated within three dimensions of sustainable development (economic, social, and environmental) (Lee \& Jan, 2019; Xu et al., 2016). The case of edu-tourism and its impact poses further challenge as the visitors (edu-tourists) are embedded in the community for the duration of their studies (temporal), as well as their impact in space (spatial) while they share living quarters with the residents. The novelty of this study is to understand residents' attitude towards this unique form of tourism, which is also a gap in the literature.

Nonetheless, in the context of SET, residents are likely to support edu-tourism because of its immediate positive economic impact; however, edu-tourism's social and environmental impacts will take longer to be felt. This study is the first attempt to investigate the residents' views after four decades of edu-tourism activities and to examine the viability of this form of tourism as a sustainable option.

\section{Methodology}

\subsection{Study Setting}

This study focused on the city of Famagusta in Northern Cyprus, which is the Turkish enclave on the island of Cyprus in the Eastern Mediterranean region (Figure A3 Appendix A). The city of Famagusta is a typical coastal town with a population of 40,920 and home to 15,097 households [100]. The city is home to four universities. In all, over 25,000 students attend these institutions, of whom about $85 \%$ are foreign students (edu-tourists). The contribution of the higher education sector in terms of revenue generation was reported as being 25\% of GDP in Northern Cyprus [101]. The number of edu-tourists is on the rise, as the number of international students traveling abroad for education is increasing [102]. The city of Famagusta was selected for this study because edu-tourism has become a lucrative form of niche tourism in Northern Cyprus, and the city of Famagusta is the main location for edu-tourists because it houses the largest university in the island and the socio-economic, as well as environmental, impacts of edu-tourism, are significant enough to be measurable. The city also has characteristics that can facilitate the identification of factors and constructs associated with residents' perceptions concerning the sustainability of edu-tourism, bearing in mind the temporal and spatial characteristics of edu-tourists. Edu-tourists spend about five years on average (i.e., bachelor, master, and doctorate levels), interact closely with and share the same space as the residents in every aspect. Such spatial and temporal characteristics of edu-tourists are unique in comparison to other forms of tourism.

\subsection{Survey Instrument}

A survey questionnaire was designed to collect data on residents' socio-demographic characteristics because their perceptions can be influenced by demographic factors, e.g., income, age, gender, length of residence $[4,5,94]$. We also embedded the latent variables, including economic, social/cultural, environmental, and quality of life satisfaction, to investigate the residents' perception of the "sustainability" of edu-tourism. The queries adopted a five-point Likert scale (" 1 = strongly agree"; 
" 5 = strongly disagree"). The research instruments were originally written in English andtranslated into Turkish. In order to overcome translation bias, two native Turkish-speaking university instructors who are senior English teachers performed the back-translation of the query items into English to minimize the translation bias/inconsistency and ensure conceptual validity [103].

About 300 survey questionnaires were distributed to residents in six areas located around the university campuses, including Sakarya, Baykal, Kaliland, Çanakkale, Karakol, and Maraş (see Figure A3). Because of the compactness of the study site, it was possible to visually specify all households within a defined geographical area, which "eliminates the need to obtain a complete sampling frame" ([104], p. 240). These areas are the main geospatial locations where university students live, commute, shop, and dine. Students are in constant contact with the residents in the above-mentioned areas of Famagusta, where the majority of city dwellers live. Therefore, the selected areas are qualified because of the unique geospatial and edu-tourism characteristics, which provided the identification of constructs associated with residents' perceptions.

The design of the questionnaires was completed based on the extant literature, knowing that there are no standardized queries to measure residents' perceptions [4]. Xu et al. [4] believe this is because "the nature and strength of the tourism impacts vary across the types of attraction and characteristics of the surrounding communities" (p. 279). In addition, because of the uniqueness of edu-tourism (spatially and temporally), two dimensions were aspirational in the design process of the queries (i.e., residents' perception based on personal benefits and community impacts) [9,105].

Prior to the pre-test of the questionnaires, two scholars from the Faculty of Tourism in the Eastern Mediterranean University (the largest University in Famagusta) were invited to assess the questionnaire. To ensure the clarity of the questionnaire items, a pilot study was conducted with 15 residents in August 2019 in three areas (out of six areas delineated for the survey). With the feedback from the residents and the specialists' assessment, one item was removed, and five items were modified for clarity and readability. Overall, 34 items were finalized, with each survey query containing 34 items. The final version of the questionnaire was formulated and formalized and included the following four sections.

Economic sustainability — this section comprised six items depicting the personal and community benefits that directly and indirectly enhance the residents' economic state. These items were based on the findings of Almeida-García et al. [5], Kim et al. [106], Gonzales et al. [94], Hammad et al. [107], and Yu et al. [61]. For example, "Edu-tourism promotes local business opportunities," "Edu-tourism increases employment opportunities."

Socio-cultural sustainability-this section comprised 10 items related to the positive or negative socio-cultural impacts of edu-tourism. These items were based on the findings of Abdullah et al. [108], Huang and Lee [109], Kim et al. [110], Scholtz and Slabbert [111], and Stylidis et al. [112]. For example, "improved understanding of other cultures," "negative influences on the local cultures."

Environmental sustainability - this section consisted of nine items and was based on the findings of Choi and Sirakaya [113], Gonzalez et al. [94], Gursoy et al. [95], Jordan et al. [114], Lee and Hsieh [115], and Sroypetch et al. [116]. For example, "Edu-tourism causes the increase of waste and pollution," "Edu-tourism contributes to increasing green spaces."

Quality of life satisfaction-this section comprised nine items and was based on the findings of Andereck and Nyaupane [1], Carneiro et al. [117], Guo et al. [118], and Su et al. [119]. For example, "Edu-tourism contributes to satisfaction with social life," "Edu-tourism contributes to overall life satisfaction."

Residents' demographics-the residents' demographics section comprised information about gender, marital status, age, education level, occupation category, income, and length of residence. For the demographic characteristics, see Table 1. 
Table 1. Profiles of the residents.

\begin{tabular}{|c|c|c|}
\hline Variable & Frequency & Percentage \\
\hline \multicolumn{3}{|l|}{ Gender } \\
\hline Mail & 152 & 50.7 \\
\hline Female & 148 & 49.3 \\
\hline \multicolumn{3}{|l|}{ Marital status } \\
\hline Single & 177 & 59.0 \\
\hline Married & 123 & 41.0 \\
\hline \multicolumn{3}{|l|}{ Age } \\
\hline $21 \sim 30$ & 130 & 43.3 \\
\hline $31 \sim 40$ & 85 & 28.3 \\
\hline $41 \sim 50$ & 53 & 17.7 \\
\hline $51 \sim 60$ & 22 & 7.3 \\
\hline Older than 60 & 10 & 3.3 \\
\hline \multicolumn{3}{|l|}{ Educational level } \\
\hline Primary or less & 69 & 23.0 \\
\hline High School & 148 & 49.3 \\
\hline University or college & 61 & 20.3 \\
\hline Graduate School (M.S. or PhD) & 22 & 7.3 \\
\hline \multicolumn{3}{|l|}{ Occupation } \\
\hline Office or teacher & 14 & 4.7 \\
\hline Farmer & 10 & 3.3 \\
\hline Worker & 45 & 15.0 \\
\hline Business & 27 & 9.0 \\
\hline Tourism & 9 & 3.0 \\
\hline Housewife & 14 & 4.7 \\
\hline Student & 75 & 25.0 \\
\hline Retired & 8 & 2.7 \\
\hline Others & 98 & 32.7 \\
\hline \multicolumn{3}{|l|}{ Length of residence } \\
\hline Less than 10 years & 44 & 14.7 \\
\hline $11-20$ years & 73 & 24.3 \\
\hline 21-30 years & 71 & 23.7 \\
\hline $31-40$ years & 55 & 18.3 \\
\hline $41-50$ years & 19 & 6.3 \\
\hline $51-60$ years & 15 & 5.0 \\
\hline Over 61 years & 23 & 7.7 \\
\hline \multicolumn{3}{|l|}{ Monthly income (TL) * } \\
\hline Less than 3000 & 51 & 17.0 \\
\hline $3000-5000$ & 99 & 33.0 \\
\hline $5000-10,000$ & 77 & 25.7 \\
\hline $10,000-15000$ & 50 & 16.7 \\
\hline More than 15,000 & 23 & 7.7 \\
\hline
\end{tabular}

Note: * Turkish Lira $(\$ 1.00=6019$ TRY $)$.

To ensure a reliable measurement instrument, all items were assessed a using factor analysis method that entails an evaluation of its reliability and validity with respect to the latent variables [120,121], which justifies how the latent variables were evaluated in terms of the observed variables [122]. Individual reliability is considered adequate when an item has a factor loading greater than 0.4 on its respective construct [123]. In assessing reliability, the loading of each indicator on its associated construct must be calculated and compared to a threshold $(x>0.4)$. See Table 2. 
Table 2. Construct/associated items.

\begin{tabular}{|c|c|c|c|}
\hline & CR & $\alpha$ & $\lambda$ \\
\hline Economic Sustainability & 0.845 & & 0.757 \\
\hline Edu-tourism increases employment opportunities & & 0.754 & \\
\hline Edu-tourism increases shopping opportunities. & & 0.737 & \\
\hline Edu-tourism increase local government tax revenues. & & 0.827 & \\
\hline Edu-tourism promote local business opportunities. & & 0.722 & \\
\hline Edu-tourism attract more investment opportunities. & & 0.650 & \\
\hline Edu-tourism play a major role in the economy of the community. & & 0.850 & \\
\hline Socio-Cultural Sustainability & 0.845 & & 0.736 \\
\hline Edu-tourism motivate to participate in cultural activities. & & 0.863 & \\
\hline Edu-tourism result in development of cultural activities. & & 0.678 & \\
\hline Edu-tourism contribute to preservation of the local culture. & & 0.803 & \\
\hline Edu-tourism provide opportunities for cultural exchange. & & 0.602 & \\
\hline Edu-tourism provides positive effects on cultural identity. & & 0.639 & \\
\hline Edu-tourism increase facilities for socialization and cultural activity. & & 0.679 & \\
\hline Edu-tourism increase crime and social problems. & & 0.743 & \\
\hline Edu-tourism modify local culture and living style. & & 0.831 & \\
\hline Edu-tourism has increased resident's pride in the local culture. & & 0.702 & \\
\hline Edu-tourism improves the image of the city. & & 0.678 & \\
\hline Environmental Sustainability & 0.834 & & 0.940 \\
\hline $\begin{array}{l}\text { Edu-tourism contribute to the Protection of the natural } \\
\text { environment and wildlife habitats }\end{array}$ & & 0.808 & \\
\hline Edu-tourism contribute to increasing environmental awareness. & & 0.803 & \\
\hline Edu-tourism contributes to increasing green spaces. & & 0.562 & \\
\hline Edu-tourism caused the increase of waste and pollution. & & 0.640 & \\
\hline Edu-tourism caused the quality of environment to decline. & & 0.689 & \\
\hline Edu-tourism improves the quality of public services. & & 0.739 & \\
\hline Edu-tourism contributes to coastal pollution. & & 0.684 & \\
\hline Edu-tourism contributes to noise pollution. & & 0.594 & \\
\hline Edu-tourism contributes to overcrowding and traffic. & & 0.861 & \\
\hline Quality of life Satisfaction & 0.857 & & 0.957 \\
\hline Edu-tourism contributes to safety well-being. & & 0.688 & \\
\hline Edu-tourism contributes to family satisfaction. & & 0.746 & \\
\hline Edu-tourism contributes to satisfaction with leisure & & 0.802 & \\
\hline Edu-tourism contributes satisfaction with spiritual life & & 0.781 & \\
\hline Edu-tourism contributes to satisfaction with cultural life & & 0.764 & \\
\hline Edu-tourism contributes to satisfaction with social life. & & 0.861 & \\
\hline Edu-tourism contributes to satisfaction with neighbors & & 0.656 & \\
\hline Edu-tourism contributes to overall life satisfaction. & & 0.824 & \\
\hline
\end{tabular}

Construct reliability is usually evaluated using Cronbach's alpha [124] and composite reliability (CR) [125]. The Cronbach's alpha for all constructs (i.e., economic sustainability, socio-cultural sustainability, environmental sustainability, and quality of life satisfaction) was greater than the suggested benchmark (i.e., $>0.60$ ). Refer to Table 2 . The CR should also be higher than 0.7 to establish internal consistency $[123,124]$. As indicated in Table 2, CR value for all latent variables are acceptable (i.e., 0.757, $0.736,0.940$, and 0.957 , respectively). These results indicate that the measurement model possesses an acceptable degree of reliability.

\subsection{Sampling and Survey Procedures}

For this research, seven areas (i.e., Bolge in Turkish) in the city of Famagusta were the target population comprising the communities of Sakarya, Karakol, Çanakkale, Baykal, Kaliland, Gulseren, and Maraş (See Figure A3). These areas are located within a less than 2-km buffer around four universities with a high degree of proximity to the main campus. The majority of international students (edu-tourists) are accommodated in these communities. There is a higher degree of interaction between the edu-tourists and households in the areas mentioned. The list of the households was obtained 
from the municipality, and the number of households for the seven regions comprised 2111 units (http://spd.gov.ct.tr/HARITALAR). See Table 3.

Table 3. Selected areas sampled for survey.

\begin{tabular}{ccc}
\hline Surveyed Areas & Number of Households & Number of Survey Questionnaires Distributed to Each Area \\
\hline Sakarya & 250 & 42 \\
Maraş & 340 & 44 \\
Kaliland & 363 & 44 \\
Çanakkale & 421 & 50 \\
Baykal & 283 & 42 \\
Gülseran & 192 & 36 \\
Karakol & 262 & 42 \\
Total & 2111 & 300 \\
\hline
\end{tabular}

Source: (http://spd.gov.ct.tr/HARITALAR).

Overall, 300 survey questionnaires were randomly distributed using a stratified sampling design to the seven areas as our strata (i.e., categories), and proportional allocation of the sample within each stratum [126]. Stratified random sampling was used to guarantee representation among the diverse areas and households [107]. Randomization was accomplished based on the municipalities' list of households and distribution of survey materials to every other household, as they appeared in the municipality's list.

The drop-off/pick-up method for household survey research was applied by delivering questionnaires by hand to residences within study areas. This method of "self-administered questionnaires has been presented as an alternative for reducing non-coverage error at a lower cost than has been the case with face-to-face interviews" ([127], p. 239). A total of 300 completed surveys were returned and used for analysis.

The data collection spanned two months (June and July 2019). The surveys were dropped off on weekends because the heads of households would be on weekend holiday (i.e., Saturday and Sunday); one of the authors supervised the field researcher to make sure that they explained the study's purposes. If the resident agreed to take part in the survey, they were handed the survey instrument and a designated convenience date for pick-up was agreed on.

\section{Data and Statistical Analysis}

\subsection{Convergent and Discriminant Validity}

Construct validity consists of convergent validity and discriminant validity. To assess convergent validity, we tested the average variance extracted (AVE) [128]. According to the results for all latent variables, the AVE was acceptable, i.e., greater than the recommended threshold level (AVE $>0.5)$. Discriminant validity is the extent to which each latent variable is distinct from the other constructs in the model [123,124]. Discriminant validity was evaluated using the Fornell-Larcker [129] criterion. According to this approach, the square root of the AVE values is compared to the latent variable correlations. The square root of each construct must be greater than its highest correlation with any other construct in order to substantiate the validity of results [130]. Moreover, comparing the values of AVE (average variance extracted), MSV (maximum shared variable), and ASV (average shared variable) shows acceptable discriminant validity; therefore, the construct validity of the measurement instrument was confirmed. Furthermore, because the CR $(>0.7)$ and AVE $(>0.5)$ were above the threshold, we concluded that it was unnecessary to remove any of the indicators used in the models with loadings ranging from 0.4 to 0.7 . In the meantime, all the factor loadings are more than the recommended value $(\lambda>0.4)$, which shows that items are categorized under the appropriate latent variables (see also, Table 4). The results of the fitness model showed that the fit statistics satisfied 
commonly accepted levels $(\mathrm{Cmin} / \mathrm{df}=1.475, \mathrm{IFI}=0.932, \mathrm{PCFI}=0.931, \mathrm{RMSEA}=0.062)$. These results provide evidence of convergent validity and discriminant validity (see Table 4).

Table 4. Construct validity (convergent and discriminant validity).

\begin{tabular}{|c|c|c|c|c|c|c|c|c|}
\hline \multirow{2}{*}{ Constructs } & \multirow{2}{*}{ AVE } & \multirow{2}{*}{ CR } & \multirow{2}{*}{ MSV } & \multirow{2}{*}{ ASV } & \multicolumn{4}{|c|}{ Fornell-Larcker Matrix } \\
\hline & & & & & EcS & ScS & EnS & QLs \\
\hline Economic Sustainability & 0.577 & 0.757 & 0.510 & 0.362 & $0.761^{\mathrm{a}}$ & 0.714 & 0.436 & 0.621 \\
\hline Socio-Cultural Sustainability & 0.528 & 0.736 & 0.519 & 0.428 & $0.714^{b}$ & 0.727 & 0.512 & 0.696 \\
\hline Environmental Sustainability & 0.512 & 0.940 & 0.314 & 0.255 & 0.436 & 0.512 & 0.716 & 0.560 \\
\hline Quality of life Satisfaction & 0.525 & 0.484 & 0.484 & 0.395 & 0.621 & 0.696 & 0.560 & 0.725 \\
\hline
\end{tabular}

Notes: ${ }^{a}$ Diagonal elements in bold denote the square root of average variance extracted. ${ }^{\mathrm{b}}$ Lower triangle: Denotes the correlations between the constructs. C.R > AVE; AVE > 0.5; AVE > MSV; AVE > ASV.

\subsection{Statistical Analysis}

Bartlett's Test of Sphericity shows a statistical significance level of $0.000<0.05$ and a Kaiser-MeyerOlkin value of 0.921 , which exceeds the recommended value (i.e., the cut-off level of 0.7 ) [131]. Therefore, the sample adequacy was confirmed (see Table 5).

Table 5. KMO (Kaiser-Meyer-Olkin) value and Bartlett's test.

\begin{tabular}{ccc}
\hline Kaiser-Meyer-Olkin Measure of Sampling Adequacy & $\mathbf{0 . 9 2 1}>\mathbf{0 . 7}$ \\
\hline & Approx. Chi-Square & 3983.63 \\
Bartlett's Test of Sphericity & df & 561 \\
& Sig. & 0.000 \\
\hline
\end{tabular}

Descriptive statistical analysis was performed using the statistical software SPSS 24 for Windows. Exploratory factor analysis (EFA) was used to gather information pertaining to the inter-correlation among variables. Using LISREL 8.80 for Windows, we conducted a confirmatory factor analysis (CFA) to assess the construct validity of the measurement instrument. The reliability and validity of the economic sustainability, socio-cultural sustainability, environmental sustainability, and quality of life satisfaction items were tested and verified. Analysis of variance (ANOVA) was conducted to examine the effect of local residents' socio-demographic features on their attitudes toward edu-tourism.

\section{Discussion}

This study examined the perceptions of residents of edu-tourism's impacts on the environment, socio-cultural situation, the economy, and life satisfaction in Famagusta in the context of sustainable tourism. A t-test was applied to examine the significant differences between two independent groups (male/female) and (single/married), and no significant difference between the mean values of the two groups was found. The relationship between gender and tourism impacts studied by Harvey et al. [132], Ribeiro et al. [133], and Ryan and Montgomery [134] are aligned with this study (see Table 6). However, Nunkoo and Gursoy [135], in their study, suggested that gender can determine residents' perceptions regarding tourism in general. Nevertheless, one should bear in mind that edu-tourism is a unique form of tourism because of its spatial and temporal characteristics; therefore, residents' perceptions of this form of tourism can be surprising. 
Table 6. Descriptive analysis and t-test for independent demographic characteristic.

\begin{tabular}{cccccccc}
\hline & & $\mathbf{N}$ & Mean & SD & t & df & Sig \\
\hline Marital Status & Single & 177 & 2.371 & 0.926 & -1.39 & 298 & 0.166 \\
Economic Sustainability & Married & 123 & 2.221 & 0.853 & & & \\
& Single & 177 & 2.482 & 0.767 & -0.814 & 298 & 0.415 \\
Socio-Cultural Sustainability & Married & 123 & 2.397 & 0.748 & & & \\
& Single & 177 & 2.511 & 0.792 & -0.075 & 298 & 0.94 \\
Environmental Sustainability & Married & 123 & 2.351 & 0.718 & & & \\
& Single & 177 & 2.493 & 0.763 & -0.044 & 298 & 0.965 \\
Quality of life Satisfaction & Married & 123 & 2.434 & 0.708 & & & \\
Gender & & & & & & & \\
Economic Sustainability & Male & 152 & 2.38 & 0.954 & -1.39 & 298 & 0.166 \\
& Female & 148 & 2.236 & 0.834 & & & \\
Socio-Cultural Sustainability & Male & 152 & 2.482 & 0.821 & -0.814 & 298 & 0.416 \\
& Female & 148 & 2.411 & 0.691 & & & \\
Environmental Sustainability & Male & 152 & 2.449 & 0.722 & 0.075 & 298 & 0.94 \\
& Female & 148 & 2.442 & 0.766 & & & \\
Quality of life Satisfaction & Male & 152 & 2.471 & 0.675 & -0.044 & 298 & 0.965 \\
& Female & 148 & 2.467 & 0.739 & & & \\
\hline
\end{tabular}

A one-way ANOVA was applied to determine whether there were any statistically significant differences between the mean values of the multilevel variables (see Table 7). A Cramér's V test was applied for correlation verification (see Table 8). The results revealed that the main socio-demographic characteristics of residents (i.e., age, level of education, length of residence) have a significant relationship with their perception of the sustainability of edu-tourism $(p<0.01)$ on economic, environment, socio-cultural, and life satisfaction dimensions. Therefore, there is a significant difference between levels of the demographic characteristics mentioned and their impacts on local residents' attitudes toward edu-tourism as a sustainable option.

Table 7. Results of one-way ANOVA.

\begin{tabular}{|c|c|c|c|c|c|c|c|c|}
\hline & \multicolumn{2}{|c|}{$\begin{array}{c}\text { Economical } \\
\text { Sustainability }\end{array}$} & \multicolumn{2}{|c|}{$\begin{array}{l}\text { Socio-Cultural } \\
\text { Sustainability }\end{array}$} & \multicolumn{2}{|c|}{$\begin{array}{l}\text { Environmental } \\
\text { Sustainability }\end{array}$} & \multicolumn{2}{|c|}{$\begin{array}{c}\text { Quality of Life } \\
\text { Satisfaction }\end{array}$} \\
\hline & BG $^{1}$ & $W^{2}$ & BG & WG & BG & WG & BG & WG \\
\hline \multicolumn{9}{|l|}{ Age } \\
\hline Sum of squares & 2.297 & 239.06 & 2.029 & 170.399 & 3.171 & 172.03 & 0.396 & 163.5 \\
\hline $\mathrm{df}$ & 4 & 295 & 4 & 295 & 4 & 295 & 4 & 295 \\
\hline $\mathrm{F}$ & \multicolumn{2}{|c|}{0.709} & \multicolumn{2}{|c|}{0.878} & \multicolumn{2}{|c|}{1.359} & \multicolumn{2}{|c|}{0.179} \\
\hline Sig. & \multicolumn{2}{|c|}{$0.000^{* *}$} & \multicolumn{2}{|c|}{$0.000^{* *}$} & \multicolumn{2}{|c|}{$0.000^{* *}$} & \multicolumn{2}{|c|}{$0.000^{* *}$} \\
\hline \multicolumn{9}{|l|}{ Education } \\
\hline Sum of squares & 73.078 & 166.278 & 51.082 & 121.346 & 47.967 & 127.23 & 48.21 & 115.69 \\
\hline $\mathrm{df}$ & 3 & 296 & 3 & 296 & 3 & 296 & 3 & 296 \\
\hline $\mathrm{F}$ & \multicolumn{2}{|c|}{42.848} & \multicolumn{2}{|c|}{41.535} & \multicolumn{2}{|c|}{37.196} & \multicolumn{2}{|c|}{41.118} \\
\hline Sig. & \multicolumn{2}{|c|}{$0.000 * *$} & \multicolumn{2}{|c|}{$0.000 * *$} & \multicolumn{2}{|c|}{$0.000 * *$} & \multicolumn{2}{|c|}{0.000 * } \\
\hline \multicolumn{9}{|l|}{ Income } \\
\hline Sum of squares & 70.952 & 170.405 & 50.632 & 121.795 & 45.792 & 129.41 & 45.352 & 118.54 \\
\hline $\mathrm{df}$ & 4 & 295 & 4 & 4 & 295 & 295 & 4 & 295 \\
\hline $\mathrm{F}$ & \multicolumn{2}{|c|}{30.707} & \multicolumn{2}{|c|}{30.659} & \multicolumn{2}{|c|}{26.097} & \multicolumn{2}{|c|}{28.216} \\
\hline Sig. & \multicolumn{2}{|c|}{$0.010^{*}$} & \multicolumn{2}{|c|}{0.063} & \multicolumn{2}{|c|}{0.072} & \multicolumn{2}{|c|}{$0.028^{*}$} \\
\hline Occupation & & & & & & & & \\
\hline Sum of squares & 15.847 & 225.51 & 8.68 & 163.747 & 9.725 & 165.47 & 5.855 & 158 \\
\hline $\mathrm{df}$ & 8 & 291 & 8 & 291 & 8 & 291 & 8 & 291 \\
\hline $\mathrm{F}$ & & & & & & & & \\
\hline Sig. & & & & & & & & \\
\hline Lengh of residence & & & & & & & & \\
\hline Sum of squares & 100.586 & 140.77 & 90.678 & 81.749 & 69.176 & 106.02 & 67.97 & 95.925 \\
\hline $\mathrm{df}$ & 6 & 293 & 6 & 293 & 6 & 293 & 6 & 293 \\
\hline $\mathrm{F}$ & & & & & & & & \\
\hline Sig. & 0.0 & 0 ** & 0.0 & & 0.0 & & & \\
\hline
\end{tabular}

Notes: $p<0.01 * * ;(p<0.05) *$; 1 - BG: Between group; 2-WG: Within group. 
Table 8. V' Cramer crosstab correlation.

\begin{tabular}{|c|c|c|}
\hline & $\mathbf{r}$ & sig. \\
\hline \multicolumn{3}{|l|}{ Age } \\
\hline Economical sustainability & 0.136 & $0.000 * *$ \\
\hline Socio-cultural Sustainability & 0.154 & $0.000 * *$ \\
\hline Environmental Sustainability & 0.116 & $0.000 * *$ \\
\hline $\begin{array}{c}\text { Quality of life satisfaction } \\
\text { Gender }\end{array}$ & 0.107 & $0.000 * *$ \\
\hline Economical sustainability & 0.087 & 0.321 \\
\hline Socio-cultural Sustainability & 0.114 & 0.143 \\
\hline Environmental Sustainability & 0.006 & 0.994 \\
\hline $\begin{array}{c}\text { Quality of life satisfaction } \\
\text { Educational level }\end{array}$ & 0.081 & 0.368 \\
\hline Economical sustainability & 0.302 & $0.000 * *$ \\
\hline Socio-cultural Sustainability & 0.279 & $0.000 * *$ \\
\hline Environmental Sustainability & 0.307 & $0.000 * *$ \\
\hline $\begin{array}{l}\text { Quality of life satisfaction } \\
\text { Length of residence }\end{array}$ & 0.318 & $0.000 * *$ \\
\hline Economical sustainability & 0.480 & $0.000 * *$ \\
\hline Socio-cultural Sustainability & 0.537 & $0.000^{* *}$ \\
\hline Environmental Sustainability & 0.520 & $0.000^{* *}$ \\
\hline $\begin{array}{c}\text { Quality of life satisfaction } \\
\text { Marital status }\end{array}$ & 0.452 & $0.000 * *$ \\
\hline Economical sustainability & 0.136 & 0.192 \\
\hline Socio-cultural Sustainability & 0.154 & 0.077 \\
\hline Environmental Sustainability & 0.116 & 0.433 \\
\hline $\begin{array}{l}\text { Quality of life satisfaction } \\
\text { Occupation }\end{array}$ & 0.107 & 0.552 \\
\hline Economical sustainability & 0.446 & $0.012 *$ \\
\hline Socio-cultural Sustainability & 0.329 & 0.034 * \\
\hline Environmental Sustainability & 0.307 & 0.061 \\
\hline $\begin{array}{l}\text { Quality of life satisfaction } \\
\text { Income }\end{array}$ & 0.414 & $0.027 *$ \\
\hline Economical sustainability & 0.393 & 0.035 * \\
\hline Socio-cultural Sustainability & 0.405 & 0.057 \\
\hline Environmental Sustainability & 0.419 & 0.059 \\
\hline Quality of life satisfaction & 0.384 & $0.042 *$ \\
\hline
\end{tabular}

Notes: $<0.01^{* *} ;<0.05^{*}$.

The level of income had a correlation with local residents' attitudes and perceptions regarding the economic and life satisfaction dimension of edu-tourism $\left(\mathbf{F}_{(4.295)}=30.707 ; p<0.01\right)$. This aspect of residents' perceptions is in accordance with the findings of Bagri and Kala [136] and Long and Kayat [137], who asserted that residents rely on tourism as a substantial source of income, especially in island states; this is also explained by the social exchange theory (SET) $[60,138,139]$. Furthermore, a significant relationship between local residents' occupation and their attitude toward the economic, socio-cultural, and quality of life dimension of edu-tourism was found $\left(\mathrm{F}_{(8.291)}=2.556 ; p<0.05\right)$. On the other hand, according to the results, local residents' type of occupation did not indicate any correlation with their perceptions of the negative or positive impacts of edu-tourism. In a way, the positive economic impact of tourism camouflages residents' perceptions of the environmental impacts, as most of the jobs are dependent on edu-tourism. Vargas-Sánchez et al. [140] asserted that the positive economic effects appear the most influential among the other impacts of tourism. Almeida-García et al. [5], in their study in a coastal town in Spain, revealed that where tourism provides jobs, some residents may be insensitive to the environmental impacts. Knowing that Famagusta has been transformed from being a small backward settlement to a bustling city because of edu-tourism, we can argue that it will take time for residents to transition from the stage of euphoria to the stage of 
antagonism (i.e., with increasing negative impacts), as explained by Doxey's Irridex model (as cited in [141]) and Butler's [142] tourism area life cycle model (TALC). Moreover, the findings of this research suggest that those respondents whose occupation depends on edu-tourism felt more positive toward edu-tourism development and its impacts. This can be explained by the fact that the majority of respondents are directly or indirectly dependent on edu-tourism, which is a dominant mode of economic activity in Famagusta. Similarly, a more negative perception was displayed by those residents who were not dependent on tourism. These findings support the research of Husbands [143] and Nunkoo and Ramkissoon [8], which revealed that being dependent on tourism leads to positive attitudes toward tourism.

Moreover, no significant association was found between marital status and gender of respondents and their perception of edu-tourism's sustainability. However, Alrwajfah et al. [144] reported that women had a less favorable view than men regarding the economic benefits of tourism in the case of Jordan. However, in this study, a significant relationship between residents' life satisfaction and their type of occupation was found $\left(\mathrm{F}_{(8.291)}=1.348 ; p<0.05\right)$. Contentment with life satisfaction is more visible among those who occupy a position directly related to the edu-tourism domain (Table 9).

Table 9. Hypotheses tests summary.

\begin{tabular}{|c|c|c|c|c|}
\hline Hypothesis & Constructs & $t$ & & Result \\
\hline \multirow[t]{4}{*}{$\mathrm{H} 1$} & ECS & -1.39 & & Not supported \\
\hline & SCS & -0.814 & & \\
\hline & ENS & -0.075 & & \\
\hline & QLS & -0.044 & & \\
\hline \multirow[t]{4}{*}{$\mathrm{H} 2$} & ECS & -1.39 & & Not supported \\
\hline & SCS & -0.814 & & \\
\hline & ENS & -0.075 & & \\
\hline & QLS & $\begin{array}{c}-0.044 \\
\text { sig. }\end{array}$ & $r$ & \\
\hline \multirow[t]{4}{*}{ H3 } & ECS & 0.000 & 0.136 & Supported \\
\hline & SCS & 0.000 & 0.154 & \\
\hline & ENS & 0.000 & 0.116 & \\
\hline & QLS & 0.000 & 0.107 & \\
\hline \multirow[t]{4}{*}{$\mathrm{H} 4$} & ECS & 0.035 & 0.393 & Supported \\
\hline & SCS & 0.057 & 0.405 & \\
\hline & ENS & 0.059 & 0.419 & \\
\hline & QLS & 0.042 & 0.384 & \\
\hline \multirow[t]{4}{*}{ H5 } & ECS & 0.012 & 0.446 & Supported \\
\hline & SCS & 0.034 & 0.329 & \\
\hline & ENS & 0.061 & 0.307 & \\
\hline & QLS & 0.027 & 0.414 & \\
\hline \multirow[t]{4}{*}{$\mathrm{H} 6$} & $\mathrm{EC}$ & 0.000 & 0.302 & Supported \\
\hline & SC & 0.000 & 0.279 & \\
\hline & $\mathrm{EN}$ & 0.000 & 0.307 & \\
\hline & QLS & 0.000 & 0.318 & \\
\hline \multirow[t]{4}{*}{ H7 } & EC & 0.000 & 0.480 & Supported \\
\hline & SC & 0.000 & 0.537 & \\
\hline & EN & 0.000 & 0.520 & \\
\hline & QLS & 0.000 & 0.452 & \\
\hline
\end{tabular}

Length of residency showed that residents have a positive perception of the economic impact of edu-tourism and its sustainability $\left(\mathrm{F}_{(6.293)}=34.893 ; p<0.01\right)$. However, this attitude was less favorable toward edu-tourism for respondents with longer residency (e.g., over 10 years). This aspect is in accordance with the findings of Almeida-García et al. [5] in a small town in Spain, where residents with over 10 years of residency perceived tourism more negatively. 
Regarding the perception of the socio-cultural impacts, different lengths of residency showed significant differences $\left(\mathrm{F}_{(6.293)}=54.167 ; p<0.01\right)$. The findings showed the same could be said about the length of residency and perceptions of environmental sustainability $\left(\mathrm{F}_{(6.293)}=31.863 ; p<0.01\right)$. This means that residents with a longer length of residency develop a more negative perception of edu-tourism's impact on the local environment. This was also valid in relation to life satisfaction $\left(\mathrm{F}{ }_{(6.293)}=34.602 ; p<0.01\right)$. This is also supported by Almeida-García's [5] study in the case of Benalmádena/Spain, which revealed that "perceptions of tourism's effects on social life and culture gradually worsen as the years of residence increase" (p. 266).

According to the results, the level of education had a significant effect on local residents' attitudes toward edu-tourism's economic impact $\left(\mathrm{F}_{(3.296)}=42.848 ; p<0.01\right)$. Perceptions of edu- tourism as a sustainable option gradually improved with a higher level of education, with more highly educated residents tending to perceive edu-tourism positively, especially if their occupation is related to educational institutions. This finding is consistent with those of Alrwajfah et al. [144], who revealed the same findings in the case of Petra/Jordan. The same was found for the perception of the socio-cultural impact of edu-tourism $\left(\mathrm{F}_{(3.296)}=41.535 ; p<0.01\right)$, which corroborates Hsu's [145] suggestion that residents' perceptions are positively influenced by their level of education. The ANOVA show significant differences $\left(\mathrm{F}_{(3.296)}=37.196 ; p<0.01\right)$ regarding the educational level of respondents within the intergroup differences when comparing respondents with primary and secondary education to those with a university education. Therefore, residents with university degrees tend to have a more positive view of the environmental impact of edu-tourism and to view it as a sustainable option. This aligns with the findings of Andereck et al. [83] and Sharma and Dyer [146]. The ANOVA shows the level of education also has a significant effect on life satisfaction $\left(\mathrm{F}_{(3.296)}=41.118 ; p<0.01\right)$, meaning that residents' perception of life satisfaction positively changed with their level of education.

A significant correlation between the age of local residents and their perception of the economic effects of edu-tourism was found $\left(\mathrm{F}_{(4.295)}=0.709 ; p<0.05\right)$, whereby older residents showed more negative attitudes. This was also true with respect to the environmental impacts $\left(\mathrm{F}_{(4.295)}=1.359\right.$; $p<0.05)$. However, such associations are inconclusive, as studies by Ahmed [147] and Tomljenovic and Faulkner [148] revealed opposite results. The study has also revealed that there is a significant correlation between the age of local residents and their attitude about life satisfaction $\left(\mathrm{F}_{(4.295)}=0.179\right.$; $p<0.05)$.

Overall, by investigating local residents' perceptions toward edu-tourism in the context of socio- cultural, economic, and environmental sustainability dimensions, the study revealed that majority of residents perceived that edu-tourism would continue to play a substantial role in the local economy. This aligns with enumerable research in various destinations (Hateftabar \& Chapuis, 2020; Gursoy et al., 2019; Gonzalez et al., 2018; Nunkoo \& Ramkissoon, 2010; Garau-Vadell et al., 2014; Zamani-Farahani \& Musa, 2008). This is also in congruence with social exchange theory (SET), which indicates that the perceived economic benefit of the tourism development is one of the main dimensions for determining the residents' perception (AP, 1992). The study has also revealed a positive perception on the sociocultural dimensions as residents are in cultural exchanges with the edu-tourists. The positive attitude can be explained by availability of cultural activities. For example, events and festivals organized for the international students, improved infrastructure, recreation facilities, and motivation to revitalize local culture (Lin et al., 2017). Lin et al. (2017) believe that positive attitude towards tourism is also attributed to resident-tourist value co-creation where residents are one of the main service providers. This is highly plausible for the case of edu-tourism as edu-tourists are in constant interaction with the residents. The study has also revealed that residents had negative attitude on the environmental dimension due to increasing air pollution, traffic jam and congestion, litter problems and uncontrolled construction (Nunkoo and So, 2016). The study has also explored residents' positive attitude on quality of life satisfaction because of edu-tourism. This is understandable as residents are experiencing emotional wellbeing (Lin et al., 2017), increasing cultural activities (Ursache, 2015), increased leisure attractions (Zaidan, 2016), and material wellbeing (Lee and Jan 2019). Whether 
residents perceive edu-tourism a sustainable option, the result indicate that notwithstanding the negative perceptions on the environment, residents view this form of tourism a sustainable option and their perception explained by social exchange theory (SET) (AP, 1992). This is highly plausible, as edu-tourism has transformed the living standards and sociocultural dynamics of the communities in this case (Abubakar et al., 2014; Katircioglu, 2010; Mehtap-Smadi \& Hashemipour, 2011).

\section{Conclusions}

This study examined residents' perception of edu-tourism in Famagusta, Northern Cyprus, where this form of tourism has become the backbone of socio-economic development and thus has various impacts. The study also intended to reveal whether this form of tourism, notwithstanding its impacts, is perceived as a sustainable option. Examining the residents' perceptions is justified on numerous grounds. First, in the era of sustainability awareness [149], residents are the main stakeholders, as tourism significantly affects their community and quality of life [5]. Secondly, residents cannot be taken for granted, as they "bear an enormous amount of collective local expert knowledge that can positively inform the decisions of the industry as well as tourism planning and management professionals, [which] is a core element of contemporary sustainable tourism discourses" ([150], p. 661).

Thus, this study focused on analyzing the factors that influence residents' attitudes toward edu-tourism and whether they perceive this form of tourism as a sustainable option in their community. The factors that influence residents' attitudes and perceptions have been classified as socio-demographic variables, including gender, age, marital status, years of residency, educational level, income, and occupation. Some authors have also used geospatial factors that might influence the perception of the residents toward the impacts of tourism $[4,151]$. Even though there is no clear conceptualization nor clearly established criteria for these classifications, the majority of studies have applied them to investigate their influences on residents' perceptions of the impacts of tourism (e.g., economic, socio-cultural, and environmental) as a tool of measurement of residents' perception of tourism's sustainability $[102,152]$.

In keeping with previous research $[137,153]$, this study found no significant effect of gender on local residents' perceptions. Level of education showed a significant variance, whereby residents with a higher level of education perceived edu-tourism's impacts more positively compared to residents with a lower level of education. These results are consistent with previous research (e.g., [154]. Local residents with a higher level of education are likely affiliated with the universities in terms of occupation. Almeida-García et al. [5] (p. 270) revealed that "attitudes toward tourism improve as residents' educational levels increase. When residents have higher levels of education, their perceptions of tourism are more positive. By contrast, residents with lower levels of education have more critical views of tourism." The findings also revealed that residents whose occupations are directly attached to the edu-tourism sector have a positive attitude on the socio-cultural dimension. They believed that the presence of edu-tourism had provided them with social activities, leisure, and intercultural benefits. Generally, these results are consistent with some previous studies $[83,155]$. The analysis also revealed the significance of the length of residency, which showed a significant amount of variance with respect to perceptions of the environmental and socio-cultural impacts. Length of residency was found to be an important predictor of negative perceptions of the impacts of educational tourism. It can be argued that, as the length of residency expands, residents tend to have a negative attitude toward tourism. This is also concerning edu-tourism, which is also explained by Doxey's Irridex model (as cited in [145]). Previous studies have also reached the same conclusion (e.g., [156,157]).

Previous studies of residents' attitudes have factored in the influence of age in different cases (e.g., [105,158]; however, the results have been inconclusive at best. Nevertheless, in our study, the younger cohort (20-39) showed a positive attitude to the economic, socio-cultural, and environmental dimensions of edu-tourism. This is opposite to the findings of Almeida-García [5] in the case of Spain. One should bear in mind that edu-tourism is a unique type of tourism, and it can engender different sensitivities within different age groups because of its spatial and temporal characteristics. 
In the end, there is no straightforward answer to the question of whether or not residents perceive edu-tourism as a sustainable option. Considering the influences of the socio-demographic factors, there is a partial consistency with the findings of other authors in different cases. The findings of this research revealed that residents' perception of edu-tourism is a partial endorsement of sustainability; however, the positive economic impacts are well recognized by the residents of Famagusta. Regarding environmental and socio-cultural sustainability, the findings are mixed because the community is heterogeneous in their attitudes toward tourism in general and edu-tourism in particular. In terms of the study's alignment with the main theoretical framework (i.e., SET), the social exchange theory holds exploratory merit $[5,8,88]$; however, it is not enough to address the complexity of the communities geographically, historically, and culturally [159].

\section{Limitations and Pathways for Future Studies}

The first limitation of this study is that it relies exclusively on quantitative research methods to try to investigate the relationships between the socio-demographic factors which influence residents' attitudes toward edu-tourism. As is demonstrated in many other studies, this study also has a limitation, which is that it does not explain why residents have such perceptions. Perhaps future studies will take this shortcoming into consideration. Another limitation is that this study focused on one city in Northern Cyprus; future studies can focus on various cities that are also involved in edu-tourism. This will allow us to explore how the spatial characteristics of the communities influence their perception. It is reasonable to argue that a qualitative method might be a better tool to delve into respondents' minds and explore an in-depth understanding of the nature of residents' perceptions, especially of the sustainability construct [160]. Therefore, qualitative research and a series of in-depth interviews can provide a detailed exploration of residents' views of the sustainability of this unique form of tourism. What have we learned from surveying residents who have given us a confusing and indecisive perspective on the pillars of sustainability (economic, social, and environmental)? The answer is that most studies of this topic show satisfaction with the short-term economic gains while giving confusing signals regarding the social and environmental as well as cultural impacts of sustainability. Future research should focus on the socio-political and economic structure of the location, as well as applying scaling specific to sustainability in order to investigate whether the three pillars of sustainability are achieved on an equal footing. The sustainability-specific scale should employ constructs including social capital, networking, and sustainability vision that are supported by the grassroots involvement of the local community [42]. Therefore, residents' perceptions alone are not enough to issue a verdict on the sustainability of edu-tourism. Given the immense variety and diversity of small cities and communities, this study can never claim to be exhaustive.

\section{Practical Implications and Contributions}

Practical and managerial implications of this study is manifold. Residents are the main stakeholders and play a decisive role in upholding 'hospitality'-as supporting factors in tourism (Ritchie and Crouch, 2003). This is even more essential in relation to edu-tourism (Abubakar et al., 2014). Understanding residents' perception is also vital in tourism governance 'since the negative effects of tourism mostly manifest on the destination level as a burden for local residents' (Bichler, 2019. P. 1). However, for the case of edu-tourism, the educational institutions are also playing an important role. Collaboration between residents and educational institutions through a co-management framework can be highly productive in achieving sustainability. Exclusion of local residents from sustainable edu-tourism planning can be detrimental to destination's long-term goals. Bichler (2019) highlighted that three spheres of management (i.e., destination management, sustainable tourism, tourism planning) warrant the fundamental role of the residents. Findings of this study provides useful insight for higher education and national tourism institutions on edu-tourism for sustainable development not to remain delirious to this form of tourism's economic impacts, but also to remain diligent to negative sociocultural and environmental impacts. 
Edu-tourism, like any other endeavor, operates within the social, political, and environmental domains of a community [161]. The most visible social implication, which is also due to positive economic impact, is the quality of life of the residents in terms of shopping, urban infrastructure, entertainment, and recreation opportunities that create venues for locals to socialize (Gursoy et al., 2002). Edu-tourists who are coming from different countries have generated intercultural interaction that broadened the views of the residents beyond their small island (Sharma et al., 2008). The presence of edu-tourists has also engendered community pride among residents for hosting international students (Andereck et al., 2007). However, the destination managers should be also diligent regarding the negative social implications such as illegal drug use, gambling, prostitution, rowdy behavior, and crime that can emanate from the presence of huge number of young students who reside in the destination for the duration of their study (Sharma et al., 2008). Political implications of edu-tourism are visible in terms of institutional quality, increase in activities of NGOs, and change in political values. Considering tourism as a social force (Farmaki, 2017), it can promote the sense of international understanding and cooperation that can enhance the peace. However, this aspect can be recommended as a topic for future studies.

Author Contributions: Conceptualization, H.A.; data curation, N.M. and H.F.; formal analysis, H.A.; investigation, H.F.; methodology, N.M.; project administration, H.A.; software, H.F.; supervision, H.A.; validation, H.A. All authors have read and agreed to the published version of the manuscript.

Funding: No funding has received for this research.

Conflicts of Interest: The authors declare no conflict of interest.

\section{Appendix A}

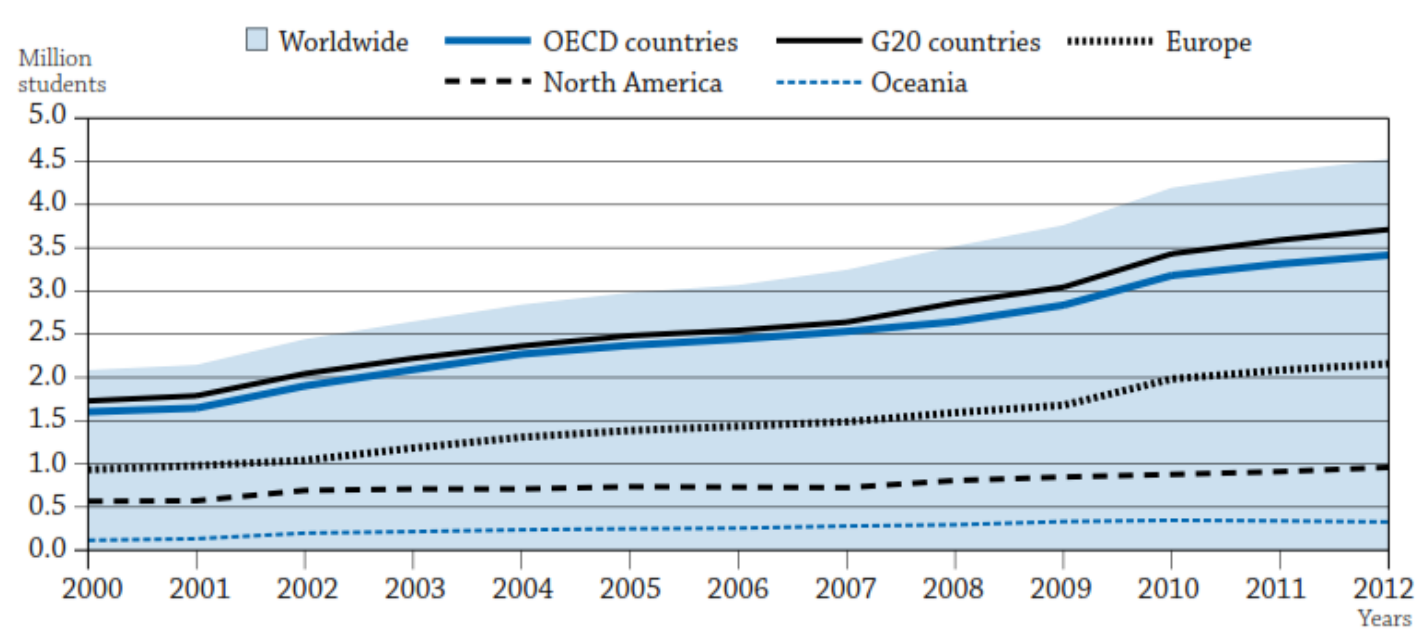

Figure A1. The number of students enrolled outside their country of citizenship (2000-2012). Source: OECD [40]. 


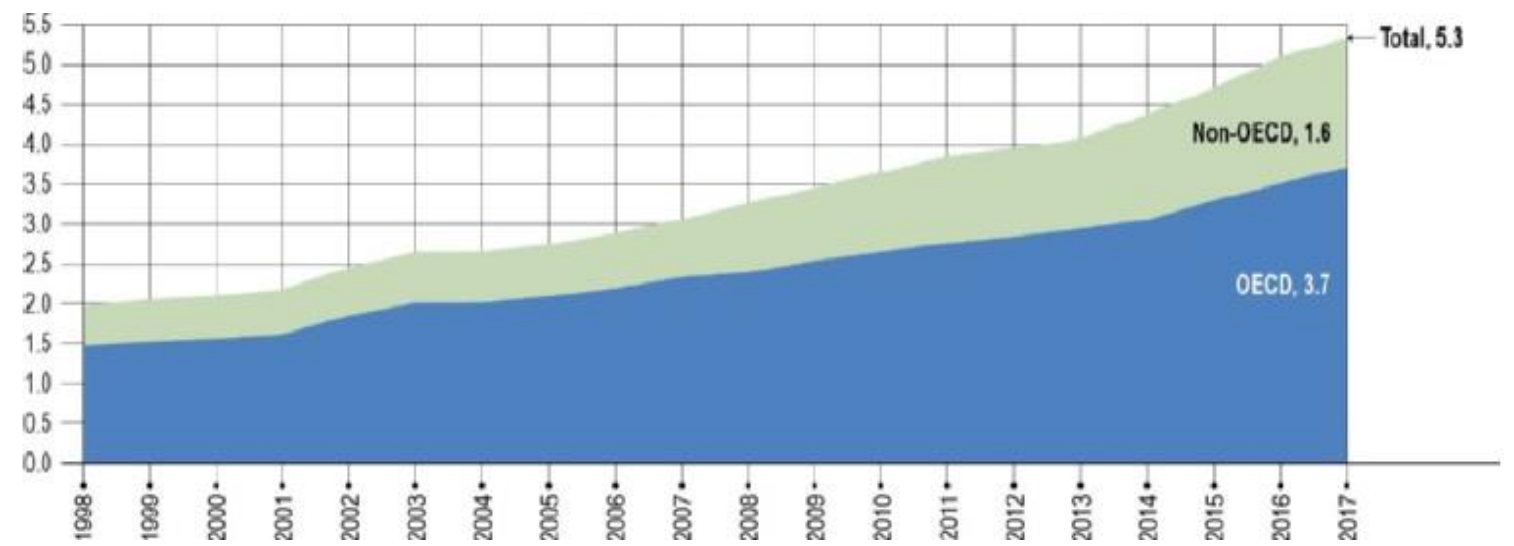

Figure A2. Number of international or foreign students enrolled in OECD and non-OECD countries. Source: OECD [41] (p. 231).

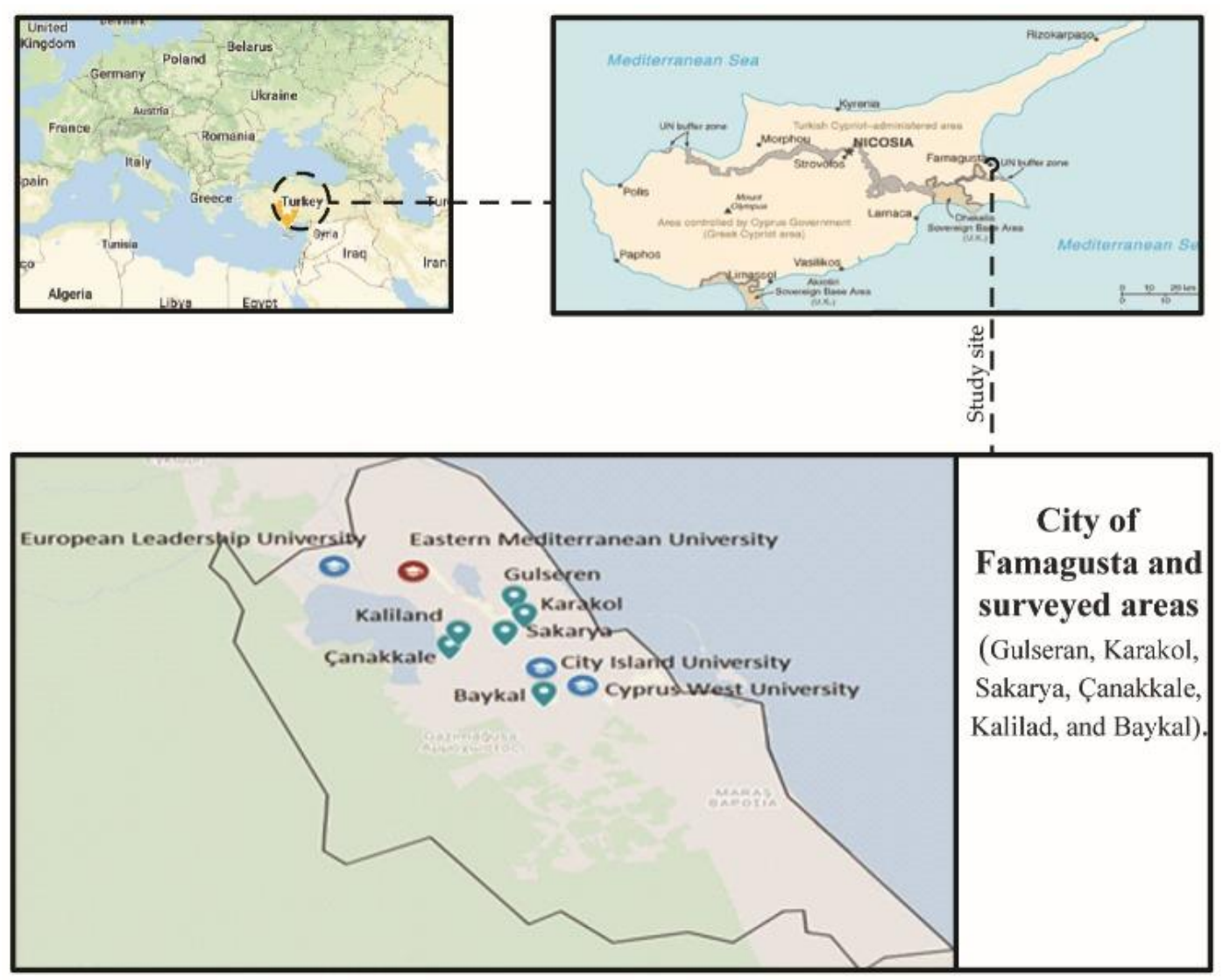

Figure A3. Study site location (Europe, Cyprus, and Famagusta).

\section{References}

1. Andereck, K.L.; Nyaupane, G.P. Exploring the nature of tourism and quality of life perceptions among residents. Travel Res. 2011, 50, 248-260. [CrossRef]

2. Kim, K.; Uysal, M.; Sirgy, M.J. How does tourism in a community impact the quality of life of community residents? Tour. Manag. 2013, 36, 527-540. [CrossRef]

3. Woo, E.; Kim, H.; Uysal, M. Life satisfaction and support for tourism development. Ann. Tour. Res. 2015, 50, 84-97. [CrossRef]

4. Xu, S.; Barbieri, C.; Anderson, D.; Leung, Y.F.; Rozier-Rich, S. Residents' perceptions of wine tourism development. Tour. Manag. 2016, 55, 276-286. [CrossRef] 
5. Almeida-Garcia, F.; Pelaez-Fernandez, M.A.; Babuena-Vazquez, A.; Cortes-Macias, R. Residents'perceptions of tourism development in Benalmadena(Spain). Tour. Manag. 2016, 54, 259-274.

6. Besculides, A.; Lee, M.E.; McCormick, P.J. Residents' perceptions of the cultural benefits of tourism. Ann. Tour. Res. 2002, 29, 303-319. [CrossRef]

7. Lv, Q.; Xie, X.; Li, Y. The Effects of Resident Empowerment on Intention to Participate in Financing: The Roles of Personal Economic Benefit and Negative Impacts of Tourism. J. China Tour. Res. 2019, 15, 541-562. [CrossRef]

8. Nunkoo, R.; Ramkissoon, H. Small island urban tourism: A residents' perspective. Curr. Issues Tour. 2010, 13, 37-60. [CrossRef]

9. Wang, Y.; Pfister, R.E. Residents' attitudes toward tourism and perceived personal benefits in a rural community. J. Travel Res. 2008, 47, 84-93. [CrossRef]

10. Brown, C.B. Tourism, crime and risk perception: An examination of broadcast media's framing of negative Aruban sentiment in the Natalee Holloway case and its impact on tourism demand. Tour. Manag. Perspect. 2015, 16, 266-277. [CrossRef]

11. Kanwal, S.; Rasheed, M.I.; Pitafi, A.H.; Pitafi, A.; Ren, M. Road and transport infrastructure development and community support for tourism: The role of perceived benefits, and community satisfaction. Tour. Manag. 2020, 77, 104014. [CrossRef]

12. Koçak, E.; Ulucak, R.; Ulucak, Z.Ş. The impact of tourism developments on CO2 emissions: An advanced panel data estimation. Tour. Manag. Perspect. 2020, 33, 100611. [CrossRef]

13. Gonzalez, V.M.; Coromia, L.; Gali, N. Overtourism: Residents' perceptions of tourism impact as an indicator of resident social carrying -case study of Spanish heritage town. Tour. Reo. 2018, 73, 277-296. [CrossRef]

14. Lee, T.H.; Jan, F.H. Can community-based tourism contribute to sustainable development? Evidence from residents' perceptions of the sustainability. Tour. Manag. 2019, 70, 368-380. [CrossRef]

15. Stylidis, D. Place attachment, perception of place and residents' support for tourism development. Tour. Plan. Dev. 2018, 15, 188-210. [CrossRef]

16. Gunn, A.C.; Var, T. Tourism Planning: Basics, Concepts, Cases; Routledge: New York, NY, USA, 2002.

17. Ritchie, B.W.; Carr, N.; Cooper, C.P. Managing Educational Tourism; Channel View Publications: Clevedon, UK, 2003.

18. Smith, S. Defining tourism: A supply-side view. Ann. Tour. Res. 1988, 15, 179-190. [CrossRef]

19. Krasnodebski, M.; Voldanova, I.; Nascimbeni, F. Overview of Caribbean Countries and Their Higher Education Systems; MENON Network EEIG: Brussels, Belgium, 2012.

20. Mehtap-Smadi, S.; Hashemipour, M. In pursuit of an international education destination: Reflections from a university in a small island state. J. Stud. Int. Educ. 2011, 15, 409-428. [CrossRef]

21. Hèrbert, Y.M.; Abdi, A.A. Critical perspectives on international education: Redefinitions, Knowledge-making, Mobilities and Changing the World. In Critical Perspectives on International Education; Herbert, Y., Abdi, A.A., Eds.; Sense publishers: Rotterdam, The Netherlands, 2013; pp. 1-42.

22. McGladdery, C.A.; Lubbe, B.A. Rethinking educational tourism: Proposing a new model and future directions. Tour. Rev. 2017, 72, 319-329. [CrossRef]

23. Abubakar, A.M.; Shneikat, B.H.T.; Oday, A. Motivational factors for educational tourism: A case study in Northern Cyprus. Tour. Manag. Perspect. 2014, 11, 58-62. [CrossRef]

24. Weaver, D.B. Alternative tourism in Montserrat. Tour. Manag. 1995, 16, 593-604. [CrossRef]

25. Garau-Vadell, J.B.; Gutierrez-Taño, D.; Diaz-Armas, R. Economic crisis and residents' perception of the impacts of tourism in mass tourism destinations. J. Destin. Mark. Manag. 2018, 7, 68-75. [CrossRef]

26. Gursoy, D.; Jurowski, C.; Uysal, M. Resident attitudes: A structural modeling approach. Ann. Tour. Res. 2002, 29, 79-105. [CrossRef]

27. Chaperon, S.; Bramwell, B. Dependency and agency in peripheral tourism development. Ann. Tour. Res. 2013, 40, 132-154. [CrossRef]

28. Scheyvens, R.; Momsen, J. Tourism in small island states: From vulnerability to strengths. J. Sustain. Tour. 2008, 16, 491-510. [CrossRef]

29. Nunkoo, R.; Gursoy, D. Political trust and residents' support for alternative and mass tourism: An improved structural model. Tour. Geogr. 2017, 19, 318-339. [CrossRef]

30. Knight, J. Internationalization remodeled: Definitions, rationales, and approaches. J. Stud. Int. Educ. 2004, 8, 5-31. [CrossRef] 
31. Larson, M.A. Internationalization of Higher Education: An. Analysis through Spatial, Network, and Mobilities Theories; Palgrave Macmillan: New York, NY, USA, 2016.

32. Hannam, K.; Butler, G.; Paris, C.M. Developments and key issues in tourism mobilities. Ann. Tour. Res. 2014, 44, 171-185. [CrossRef]

33. Urry, J. Mobilities; Polity Press: Cambridge, UK, 2007.

34. Xin, S.; Tribe, J.; Chambers, D. Conceptual research in tourism. Ann. Tour. Res. 2007, 41, 66-88. [CrossRef]

35. Bodger, D. Leisure, learning, and travel. J. Phys. Educ. Recreat. Dance 1998, 69, 28-31. [CrossRef]

36. Matoga, L. The Erasmus Programme in the development of educational tourism in Europe. In Proceedings of the in EIIC-The 3rd Electronic International Interdisciplinary Conference (No. 1). 2014. Available online: http://www.eiic.cz/archive/?vid=1\&aid=2\&kid=20301-99 (accessed on 19 December 2019).

37. Antiado, D.F.; Castillo, F.G.; Tawadrous, M.I. Educational Tourism in Dubai: The Global Higher Education Hub across Culture. In Leadership, Innovation and Entrepreneurship as Driving Forces of the Global Economy; Benlamri, R., Sparer, M., Eds.; Springer: Cham, Switzerland, 2017; pp. 543-551.

38. (OECD) Organization for Economic Cooperation and Development. Education at a Glance 2019: OECD Indicators; OECD Publishing: Paris, France, 2019. [CrossRef]

39. (OECD) Organization for Economic Cooperation and Development. Education at a Glance 2015: OECD Indicators; OECD Publishing: Paris, France, 2015. Available online: http://www.oecd.org/education/educationat-a-glance-2015.htm (accessed on 3 January 2020).

40. Richards, G.; Duif, L. Small Cities with Big Dreams: Creative Placemaking and Branding Strategies; Routledge: New York, NY, USA, 2019.

41. YÖDAK (n.d). Higher Education Planning, Accreditation, Evaluation and Coordination Council North Cyprus. Available online: https://enqa.eu/wp-content/uploads/2019/10/YODAK.pdf (accessed on 3 January 2020).

42. Abbott, A.; Silles, M. Determinants of international student migration. World Econ. 2016, 39, 621-635. [CrossRef]

43. Katircioglu, S.T. Revisiting the tourism-led-growth hypothesis for Turkey using the bounds test and Johansen approach for cointegration. Tour. Manag. 2009, 30, 17-20. [CrossRef]

44. Guslev, A. Sustainable tourism industry in the context of globalization. Adv. Sci. J. 2015, 2015, 23-26. [CrossRef]

45. De Kadt, E. Tourism: Passport to Development. In Perspectives on the Social and Cultural Effects of Tourism in Developing Countries; Oxford University Press: Oxford, UK, 1979.

46. Dolincar, S.; Matus, K. Nothing new in research on environmentally sustainable tourism? 2007. Available online: http://ro.uow.edu.au/cgi/viewcontent.cgi?article=1395\&context=commpapers (accessed on 15 January 2020).

47. Butler, R.W. Sustainable tourism: A state-of-the-art review. Tour. Geogr. 1999, 1, 7-25. [CrossRef]

48. Robinson, D.; Newman, S.P.; Stead, S.M. Community perceptions link environmental decline reduced support for tourism development in small island states: A case study in the Turks and Caicos Islands. Mar. Policy 2019, 108, 103671. [CrossRef]

49. Parra-López, E.; Martínez-González, J.A. Tourism research on island destinations: A review. Tour. Rev. 2018, 73, 133-155. [CrossRef]

50. Seetanah, B.; Fauzel, S. An Empirical Analysis of the Impact of Foreign Direct Investment on Tourism Development: The Mauritian Case. Tour. Anal. 2019, 24, 517-529. [CrossRef]

51. Fennell, D. Ecotourism: An. Introduction; Routledge: London, UK, 1999.

52. Warner, J. North Cyprus: Tourism and the challenge of non-recognition. J. Sustain. Tour. 1999, 7, $128-145$. [CrossRef]

53. Pasquinelli, C. Building from scratch? An "inner connectivity" framework for soft urban tourism development. Int. J. Tour. Cities 2016, 2, 248-256. [CrossRef]

54. Cottrell, S.P.; Vaske, J.J.; Shen, F.; Ritter, P. Resident perceptions of sustainable tourism in Chongdugou, China. Soc. Nat. Resour. 2007, 20, 511-525. [CrossRef]

55. Ernoul, L. Residents' perception of tourist development and the environment: A study from Morocco. Int. J. Sustain. Dev. World Ecol. 2009, 16, 228-233. [CrossRef]

56. Kwan, A.V.C.; McCartney, G. Mapping resident perceptions of gaming impact. J. Travel Res. 2005, 44, 177-187. [CrossRef] 
57. Rasoolimanesh, S.M.; Jaafar, M. Sustainable tourism development and residents' perceptions in World Heritage Site destinations. Asia Pac. J. Tour. Res. 2017, 22, 34-48. [CrossRef]

58. Rasoolimanesh, S.M.; Jaafar, M.; Kock, N.; Ramayah, T. A revised framework of social exchange theory to investigate the factors influencing residents' perceptions. Tour. Manag. Perspect. 2015, 16, 335-345. [CrossRef]

59. Yu, C.P.; Chancellor, H.C.; Cole, S.T. Measuring residents' attitudes toward sustainable tourism: A reexamination of the sustainable tourism attitude scale. J. Travel Res. 2011, 50, 57-63. [CrossRef]

60. Akyeampong, O.A. Pro-poor tourism: Residents' expectations, experiences and perceptions in the Kakum National Park Area of Ghana. J. Sustain. Tour. 2011, 19, 197-213. [CrossRef]

61. Ko, D.W.; Stewart, W.P. A structural equation model of residents' attitudes for tourism development. Tour. Manag. 2002, 23, 521-530. [CrossRef]

62. Long, P.T.; Perdue, R.R.; Allen, L. Rural resident tourism perceptions and attitudes by community level of tourism. J. Travel Res. 1990, 28, 3-9. [CrossRef]

63. Rasoolimanesh, S.M.; Ali, F.; Jaafar, M. Modeling residents' perceptions of tourism development: Linear versus non-linear models. J. Destin. Mark. Manag. 2018, 10, 1-9. [CrossRef]

64. Weaver, D.B.; Lawton, L.J. Resident perceptions of a contentious tourism event. Tour. Manag. 2013, 37, 165-175. [CrossRef]

65. Zamani-Farahani, H.; Musa, G. Residents' attitudes and perception towards tourism development: A case study of Masooleh, Iran. Tour. Manag. 2008, 29, 1233-1236. [CrossRef]

66. Liu, Y.; Nie, L.; Wang, F.; Nies, Z. The impact of tourism development on local residents in Bama, Guangxi, China. Tour. Econ. 2015, 21, 1133-1148. [CrossRef]

67. Tokarchuk, O.; Gabriele, R.; Maurer, O. Tourism intensity impact on satisfaction with life of German residents. Tour. Econ. 2016, 22, 1315-1331. [CrossRef]

68. Madrigal, R. Residents' perceptions and the role of government. Ann. Tour. Res. 1995, 22, 86-102. [CrossRef]

69. Moscardo, G. Exploring social representations of tourism planning: Issues for governance. J. Sustain. Tour. 2011, 19, 423-436. [CrossRef]

70. Boley, B.B.; McGehee, N.G.; Perdue, R.R.; Long, P. Empowerment and resident attitudes toward tourism: Strengthening the theoretical foundation through a Weberian lens. Ann. Tour. Res. 2014, 49, 33-50. [CrossRef]

71. Joo, D.; Tasci, A.D.; Woosnam, K.M.; Maruyama, N.U.; Hollas, C.R.; Aleshinloye, K.D. Residents' attitude towards domestic tourists explained by contact, emotional solidarity and social distance. Tour. Manag. 2018, 64, 245-257. [CrossRef]

72. Moghavvemi, S.; Woosnam, K.M.; Paramanathan, T.; Musa, G.; Hamzah, A. The effect of residents' personality, emotional solidarity, and community commitment on support for tourism development. Tour. Manag. 2017, 63, 242-254. [CrossRef]

73. Cropanzano, R.; Mitchell, M.S. Social exchange theory: An interdisciplinary review. J. Manag. 2005, 31, 874-900. [CrossRef]

74. Nunkoo, R. Toward a more comprehensive use of social exchange theory to study residents' attitudes to tourism. Procedia Econ. Financ. 2016, 39, 588-596. [CrossRef]

75. López, M.F.; Virto, N.R.; Manzano, J.A.; Miranda, J.G. Residents' attitude as determinant of tourism sustainability: The case of Trujillo. J. Hosp. Tour. Manag. 2018, 35, 36-45. [CrossRef]

76. Olya, H.G.; Shahmirzdi, E.K.; Alipour, H. Pro-tourism and anti-tourism community groups at a world heritage site in Turkey. Curr. Issues Tour. 2019, 22, 763-785. [CrossRef]

77. Wang, W.C. The effect of early-life outdoor experiences on residents' attitudes towards sustainable tourism within an urban context. J. Outdoor Recreat. Tour. 2019, 25, 1-9. [CrossRef]

78. Bastias-Perez, P.; Var, T. Perceived impacts of tourism by residents. Ann. Tour. Res. 1995, 22, $208-210$. [CrossRef]

79. Casado Diaz, M.A. Socio demographic impacts of residential tourism: A case study of Torrevieja, Spain. Int. J. Tour. Res. 1999, 1, 223-237. [CrossRef]

80. Sharma, B.; Gursoy, D. An examination of changes in residents' perceptions of tourism impacts over time: The impact of residents' socio-demographic characteristics. Asia Pac. J. Tour. Res. 2015, 20, 1332-1352. [CrossRef]

81. Andereck, K.L.; Valentine, K.M.; Knopf, R.C.; Vogt, C.A. Residents' Perceptions of Community Tourism Impacts. Ann. Tour. Res. 2005, 32, 1056-1076. [CrossRef] 
82. Nunkoo, R.; Smith, S.L.; Ramkissoon, H. Residents' attitudes to tourism: A longitudinal study of 140 articles from 1984 to 2010. J. Sustain. Tour. 2013, 21, 5-25. [CrossRef]

83. Thibaut, J.W.; Kelley, H.H. The Social Psychology of Groups; John Wiley: New York, NY, USA, 1959.

84. Homans, G.C. Social Behavior: Its Elementary Forms; Routledge: London, UK, 1961.

85. Fan, L.; Mahmood, M.; Uddin, M.A. Supportive Chinese supervisor, innovative international students: A social exchange theory perspective. Asia Pac. Educ. Rev. 2019, 20, 101-115. [CrossRef]

86. Gursoy, D.; Boğan, E.; Dedeoğlu, B.B.; Çalışkan, C. Residents' perceptions of hotels' corporate social responsibility initiatives and its impact on residents' sentiments to community and support for additional tourism development. J. Hosp. Tour. Manag. 2019, 39, 117-128. [CrossRef]

87. Bichler, B.F. Designing tourism governance: The role of local residents. J. Destin. Mark. Manag. 2019, 2019, 100389. [CrossRef]

88. Haley, A.J.; Snaith, T.; Miller, G. The social impacts of tourism a case study of Bath, UK. Ann. Tour. Res. 2005, 32, 647-668.

89. Heath, A.; Heath, L.E. Rational Choice and Social Exchange: A Critique of Exchange Theory; Cambridge University Press: London, UK, 1976.

90. Goodwin, H. The Challenge of Overtourism: Responsible Tourism Partnership Working Papers. 2017. Available online: https://haroldgoodwin.info/pubs/RTP \T1 \textquoterightWP4Overtourism01\T1 textquoteright2017.pdf (accessed on 27 January 2020).

91. Seraphin, H.; Sheeran, P.; Pilato, M. Over-tourism and the fall of Venice as a destination. J. Destin. Mark. Manag. 2018, 9, 374-376. [CrossRef]

92. Gursoy, D.; Ouyang, Z.; Nunkoo, R.; Wei, W. Residents' impact perceptions of and attitudes towards tourism development: A meta-analysis. J. Hosp. Mark. Manag. 2019, 28, 306-333. [CrossRef]

93. Nunkoo, R.; Ramkissoon, H. Applying the means-end chain theory and the laddering technique to the study of host attitudes to tourism. J. Sustain. Tour. 2009, 17, 337-355. [CrossRef]

94. Crossman, A. Understanding Social Exchange Theory. 2017. Available online: https://www.thoughtco.com/ social-exchange-theory-3026634 (accessed on 27 January 2020).

95. Hacking, T.; Guthrie, P. A framework for clarifying the meaning of Triple Bottom-Line, Integrated, and Sustainability Assessment. Environ. Impact Assess. Rev. 2008, 28, 73-89. [CrossRef]

96. Gu, H.; Ryan, C. Place attachment, identity and community impacts of tourism-The case of a Beijing hutong. Tour. Manag. 2008, 29, 637-647. [CrossRef]

97. Choi, H.C.; Murray, I. Resident attitudes toward sustainable community tourism. J. Sustain. Tour. 2010, 18, 575-594. [CrossRef]

98. Fachrudin, H.T.; Lubis, M.D. Planning for riverside area as water tourism destination to improve quality of life local residents, case study: Batuan-Sikambing River, Medan, Indonesia. Procedia-Soc. Behav. Sci. 2016, 234, 434-441. [CrossRef]

99. Sinclair-Maragh, G. Demographic analysis of residents' support for tourism development in Jamaica. J. Destin. Mark. Manag. 2017, 6, 5-12. [CrossRef]

100. (SPO) State Planning Organization. Statistical Yearbook 2017; State Planning Organization: Nicosia, Cyprus, 2018. Available online: http://www.devplan.org/Ist_yillik/IST-YILLIK-2017.pdf (accessed on 4 February 2020).

101. (SPO) State Planning Organization. Economic and Social Indicators; State Planning Organization: Nicosia, Cyprus, 2019.

102. Huh, C.; Vogt, C.A. Changes in residents' attitudes toward tourism over time: A cohort analytical approach. J. Travel Res. 2008, 46, 446-455. [CrossRef]

103. Tyupa, S. A theoretical framework for back-translation as a quality assessment tool. New Voices Transl. Stud. 2011, 7, 35-46.

104. Lynn, P. The advantage and disadvantage of implicitly stratified sampling. Methods Data Anal. 2019, 13, 253-266.

105. Smith, J.W.; Anderson, D.H.; Davenport, M.A.; Leahy, J.E. Community benefits from managed resource areas: An analysis of construct validity. J. Leis. Res. 2013, 45, 192-213. [CrossRef]

106. Kim, G.; Duffy, L.N.; Moore, D. Tourist attractiveness: Measuring residents' perception of tourists. J. Sustain. Tour. 2020, 28, 898-916. [CrossRef]

107. Hammad, N.; Ahmad, S.Z.; Papastathopoulos, A. Residents' perceptions of the impact of tourism in Abu Dhabi, United Arab Emirates. Int. J. Cult. Tour. Hosp. Res. 2017, 11, 551-572. [CrossRef] 
108. Abdullah, N.H.; Patterson, I.; Pegg, S. Recreation \& tourism organizers' and residents' views about the benefits and costs: The case of Monsoon Cup International Sailing Regatta, Malaysia. Int. J. Sport Manag. $2015,17,46-66$.

109. Huang, S.S.; Lee, I.S. Motivations for attending a multicultural festival: Visitor ethnicity matters. Anatolia 2015, 26, 92-95. [CrossRef]

110. Kim, W.; Jun, H.; Walker, M.; Drane, D. Evaluating the perceived social impacts of hosting large-scale sport tourism events: Scale development and validation. Tour. Manag. 2015, 48, 21-32. [CrossRef]

111. Scholtz, M.; Slabbert, E. Tourism in not just about the Money: A Comparison of Three South African Communities. Afr. J. Hosp. Tour. Leis. 2017, 6, 1-21.

112. Stylidis, D.; Biran, A.; Sit, J.; Szivas, E.M. Residents' support for tourism development: The role of residents' place image and perceived tourism impacts. Tour. Manag. 2014, 45, 260-274. [CrossRef]

113. Choi, H.C.; Sirakaya, E. Sustainability indicators for managing community tourism. Tour. Manag. 2006, 12, 74-89. [CrossRef]

114. Jordan, E.J.; Lesar, L.; Spencer, D.M. Clarifying the interrelations of residents' perceived tourism-related stress, stressors, and impacts. J. Travel Res. 2019, 0047287519888287. [CrossRef]

115. Lee, T.H.; Hsieh, H.P. Indicators of sustainable tourism: A case study from a Taiwan's wetland. Ecol. Indic. 2016, 67, 779-787. [CrossRef]

116. Sroypetch, S.; Carr, N.; Duncan, T. Host and backpacker perceptions of environmental impacts of backpacker tourism: A case study of the Yasawa Islands, Fiji. Tour. Hosp. Res. 2018, 18, 203-213. [CrossRef]

117. Carneiro, M.J.; Eusébio, C.; Caldeira, A. The influence of social contact in residents' perceptions of the tourism impact on their quality of life: A structural equation model. J. Qual. Assur. Hosp. Tour. 2018, 19, 1-30. [CrossRef]

118. Guo, Y.; Kim, S.; Chen, Y. Shanghai residents' perceptions of tourism impacts and quality of life. J. China Tour. Res. 2014, 10, 142-164. [CrossRef]

119. Su, L.; Huang, S.; Huang, J. Effects of destination social responsibility and tourism impacts on residents' support for tourism and perceived quality of life. J. Hosp. Tour. Res. 2018, 42, 1039-1057. [CrossRef]

120. Chin, W.W. How to write up and report PLS analyses. In Handbook of Partial Least Squares; Springer: Berlin/Heidelberg, Germany, 2010; pp. 655-690.

121. Hair, J.; Hollingsworth, C.L.; Randolph, A.B.; Chong, A.Y.L. An updated and expanded assessment of PLS-SEM in information systems research. Ind. Manag. Data Syst. 2017, 117, 442-458. [CrossRef]

122. Hair, J.F.; Black, W.C.; Babin, B.J.; Anderson, R.E. Multivariate Data Analysis; Pearson Education: New York, NY, USA, 2010.

123. Carmines, E.G.; Zeller, R.A. Reliability and Validity Assessment; Sage publications: London, UK, 1979.

124. Cronbach, L.J.; Furby, L. How we should measure "change": Or should we? Psychol. Bull. 1970, $74,68$. [CrossRef]

125. Anderson, J.C.; Gerbing, D.W. Structural equation modeling in practice: A review and recommended two-step approach. Psychol. Bull. 1988, 103, 411. [CrossRef]

126. Bagozzi, R.P.; Yi, Y. On the evaluation of structural equation models. J. Acad. Mark. Sci. 1988, 16, 74-94. [CrossRef]

127. Bryman, A. Social Research Methods, 4th ed.; Oxford University Press: Oxford, UK, 2012.

128. Steele, J.; Bourke, L.; Luloff, A.E.; Liao, P.S.; Theodori, G.L.; Krannich, R.S. The drop-off/pick-up method for household survey research. Community Dev. 2001, 32, 238-250. [CrossRef]

129. Fornell, C.; Larcker, D.F. Evaluating structural equation models with unobservable variables and measurement error. J. Mark. Res. 1981, 18, 39-50. [CrossRef]

130. Hair, J.F.; Sarstedt, M.; Ringle, C.M.; Mena, J.A. An assessment of the use of partial least squares structural equation modeling in marketing research. J. Acad. Mark. Sci. 2012, 40, 414-433. [CrossRef]

131. Hair, J.F.; Black, W.C.; Babin, B.J.; Anderson, R.E.; Tatham, R.L. Multivariate Data Analysis; Prentice Hall: Upper Saddle River, NJ, USA, 1998.

132. Harvey, M.J.; Hunt, J.; Harris, C.C. Gender and community tourism dependence level. Ann. Tour. Res. 1995, 22, 349-366. [CrossRef]

133. Ribeiro, M.A.; Oom do Valle, P.; Silva, J.A. Residents' attitudes towards tourism development in Cape Verde Islands. Tour. Geogr. 2013, 15, 654-679. [CrossRef] 
134. Ryan, C.; Montgomery, D. The attitudes of Bakewell residents to tourism and issues in community responsive tourism. Tour. Manag. 1994, 15, 358-369. [CrossRef]

135. Nunkoo, R.; Gursoy, D. Residents' support for tourism: An identity perspective. Ann. Tour. Res. 2012, 39, 243-268. [CrossRef]

136. Bagri, S.C.; Kala, D. Residents' attitudes toward tourism development and impacts in Koti-Kanasar, Indroli, Pattyur tourism circuit of Uttarakhand state, India. PASOS 2016, 14, 23-39. [CrossRef]

137. Long, P.H.; Kayat, K. Residents' perceptions of tourism impact and their support for tourism development: The case study of Cuc Phuong National Park, Ninh Binh Province, Vietnam. Eur. J. Tour. Res. 2011, 4, 123-146.

138. Gursoy, D.; Rutherford, D.G. Host attitudes toward tourism: An improved structural model. Ann. Tour. Res. 2004, 31, 495-516. [CrossRef]

139. Látková, P.; Vogt, C.A. Residents' attitudes toward existing and future tourism development in rural communities. J. Travel Res. 2012, 51, 50-67. [CrossRef]

140. VARGAS-SÁNCHEZ, A.; Porras-Bueno, N.; Plaza-Mejia, M.D.L.A. RESIDENTS 'ATTITUDES TOWARDS TOURISM DEVELOPMENT IN THE SPANISH PROVINCE OF HUELVA. Narodnostopan. Arch. Int. Ed. 2009, 2009, 31-62.

141. Mason, P.; Cheyne, J. Residents' attitudes to proposed tourism development. Ann. Tour. Res. 2000, 27, 391-411. [CrossRef]

142. Butler, R.W. The concept of a tourist area cycle of evolution: Implications for management of resources. Can. Geogr. 1980, 24, 5-12. [CrossRef]

143. Husbands, W. Social status and perception of tourism in Zambia. Ann. Tour. Res. 1989, 16, $237-253$. [CrossRef]

144. Alrwajfah, M.M.; Almeida-García, F.; Cortés-Macías, R. Residents' perceptions and satisfaction toward tourism development: A case study of Petra Region, Jordan. Sustainability 2019, 11, 1907. [CrossRef]

145. Hsu, C.H. Tao Residents' Perceptions of Social and Cultural Impacts of Tourism in Lan-Yu. Master's Thesis, Taiwan Clemson University, Clemson, SC, USA, 2006. Unpublished.

146. Sharma, B.; Dyer, P. Residents' involvement in tourism and their perceptions of tourism impacts. Benchmarking 2009, 16, 351-371. [CrossRef]

147. Ahmed, S. Understanding residents' reaction to tourism marketing strategies. J. Travel Res. 1986, 25, 13-18. [CrossRef]

148. Tomljenovic, R.; Faulkner, B. Tourism and older residents in a Sunbelt resort. Ann. Tour. Res. 1999, $27,93-114$. [CrossRef]

149. Laine, M. A new era of sustainability: CEO reflections on progress to date, challenges ahead and the impact of the journey toward a sustainable economy. Soc. Environ. Acc. J. 2011, 31, 106-107. [CrossRef]

150. Lawton, L.J.; Weaver, D.B. Using residents' perceptions research to inform planning and management for sustainable tourism: A study of the Gold Coast Schoolies Week, a contentious tourism event. J. Sustain. Tour. 2015, 23, 660-682. [CrossRef]

151. Xu, S.; Leung, Y.-F.; Barbieri, C. Characterizing themed touring routes: A geospatial and tourism evaluation of wine trails. Tour. Plan. Dev. 2016, 13, 168-184. [CrossRef]

152. Ribeiro, M.A.; Silva, J.A.; Oom do, V.P. Measuring residents' attitude towards sustainable tourism: The validity of sustainable tourism attitude scale (SUS-TAS) in Cape Verde islands. In Proceedings of the TTRA 2014 International Conference: Tourism and the new Global Economy, Bruges, Belgium, 18-20 June 2014; pp. 282-294.

153. Haralambopoulos, N.; Pizam, A. Perceived impacts of tourism: The case of Samos. Ann. Tour. Res. 1996, 23, 503-526. [CrossRef]

154. Hernandez, S.A.; Cohen, J.; Garcia, H.L. Residents' attitudes towards an instant resort enclave. Ann. Tour. Res. 1996, 23, 755-779. [CrossRef]

155. Teye, V.; Sirakaya, E.; Sönmez, S.F. Residents' attitudes toward tourism development. Ann. Tour. Res. 2002, 29, 668-688. [CrossRef]

156. Perdue, R.R.; Long, P.T.; Allen, L. Resident support for tourism development. Ann. Tour. Res. 1990, 17, 586-599. [CrossRef]

157. Lankford, S.V.; Howard, D.R. Developing a tourism impact attitude scale. Ann. Tour. Res. 1994, 21, 121-139. [CrossRef] 
158. Bujosa, A.; Rossell, O.J. Modelling environmental attitudes toward tourism. Tour. Manag. 2007, 28 , $688-695$. [CrossRef]

159. Blackstock, K. A critical look at community based tourism. Community Dev. J. 2005, 40, 39-49. [CrossRef]

160. Merriam, S. Qualitative Research: A Guide to Design and Implementation; Jossey-Bass: San Francisco, CA, USA, 2009.

161. Shields, R. Globalization and International Education; Bloomsbury: London, UK, 2013.

(C) (1)

(C) 2020 by the authors. Licensee MDPI, Basel, Switzerland. This article is an open access article distributed under the terms and conditions of the Creative Commons Attribution (CC BY) license (http://creativecommons.org/licenses/by/4.0/). 